\title{
Young but distinct: description of Eubranchus malakhovi sp.n. a new, recently diverged nudibranch species (Gastropoda: Heterobranchia) from the Sea of Japan
}

\section{I.A. Ekimova ${ }^{1 *}$, A.L. Mikhlina², O.A. Vorobyeva ${ }^{1}$, T.I. Antokhina ${ }^{3}$, V.G. Tambovtseva ${ }^{4}$, D.M. Schepetov ${ }^{1,4}$}

\author{
${ }^{1}$ Invertebrate Zoology Department, Lomonosov Moscow State University, Leninskie Gory 1-12, \\ Moscow, 119234 Russia. \\ ${ }^{2}$ White Sea Biological Station, Lomonosov Moscow State University, Leninskie Gory 1-12, Moscow, \\ 119234 Russia. \\ ${ }^{3}$ Laboratory of Marine Invertebrate Morphology and Ecology, A.N. Severtsov Institute of Ecology \\ and Evolution RAS, Leninsky Prospekt 33, Moscow, 119071 Russia. \\ ${ }^{4}$ Laboratory of evolutionary developmental biology, N.K. Koltzov Institute of Developmental \\ Biology RAS, Vavilova str. 26-1, Moscow, 119334 Russia. \\ * Corresponding author: irenekimova@gmail.com
}

\begin{abstract}
In this paper we perform an integrative investigation of the Eubranchus odhneri-Eubranchus sanjuanensis species complex. Several specimens morphologically similar to E. sanjuanensis were collected in the Sea of Japan. However, preliminary molecular data indicated that they were closer to the Arctic species E. odhneri. For our analysis we obtained new data on mitochondrial COI and 16S rRNA, and nuclear histone $\mathrm{H} 3$ and 18S rRNA molecular markers to reconstruct their phylogeny (Bayesian Inference and Maximum Likelihood approaches), delimit species with ASAP, bPTP and GMYC analyses and estimate divergence times of putative species. We also studied morphological and ecological features including external morphology, colouration, jaw and radular morphology, configuration of the reproductive system, ultrastructure of cnidosacs, and determination of possible diet preferences. Our results show that specimens from the Sea of Japan represent a new species described herein, Eubranchus malakhovi sp.n. It differs both morphologically and genetically from its closely related species, the Arctic E. odhneri and the North-East Pacific E. sanjuanensis. The new species is closely related to E. odhneri with low mtDNA divergence, and our divergence time estimations suggest these species split $\sim 1.5$ Mya.

How to cite this article: Ekimova I.A., Mikhlina A.L., Vorobyeva O.A., Antokhina T.I., Tambovtseva V.G., Schepetov D.M. Young but distinct: description of Eubranchus malakhovi sp.n. a new, recently diverged nudibranch species (Gastropoda: Heterobranchia) from the Sea of Japan // Invert. Zool. Vol.18. No.3. P.197-222, Table S1, Fig. S1, Data S1. doi: 10.15298/invertzool.18.3.02
\end{abstract}

KEY WORDS: Nudibranchia, North-West Pacific, Arctic, species delimitation, molecular phylogeny, integrative taxonomy, Mollusca.

The paper is devoted to 70th anniversary of Prof. V.V. Malakhov.

Статья посвящена 70-летию со дня рождения проф., акад. В.В. Малахова. 


\title{
Молодой, но отличный: описание нового вида голожаберных моллюсков Eubranchus malakhovi sp.n. (Gastropoda: Heterobranchia) из Японского моря
}

\section{И.А. Екимова ${ }^{1 *}$, А.Л. Михлина², О.А. Воробьева ${ }^{1}$, Т.И. Антохина ${ }^{3}$, В.Г. Тамбовцева ${ }^{4}$, Д.М. Щепетов ${ }^{1,4}$}

\author{
${ }^{1}$ Кафедра зоологии беспозвоночных, Московский государственный университет им. М.В. \\ Ломоносова, Ленинские горы 1-12, Москва, 119234 Россия. \\ ${ }^{2}$ Беломорская биологическая станиия МГУ, Московский государственный университет им. \\ М.В. Ломоносова, Ленинские горы 1-12, Москва, 119234 Россия. \\ ${ }^{3}$ Лаборатория морфологии и экологии морских беспозвоночных, Институт проблем эколо- \\ гии и эволюиии им. А.Н. Севериова РАН, Ленинский проспект 33, Москва, 119071 Россия. \\ ${ }^{4}$ Лаборатория эволючионной биологии развития, Институт биологии развития им. Н.К. \\ Кольчова РАН, ул. Вавилова 26, Москва, 119334 Россия. \\ * Aвтор-корреспондент: irenekimova@gmail.com
}

РЕЗЮМЕ: В этой статье мы представляем интегративный анализ комплекса видов Eubranchus odhneri - Eubranchus sanjuanensis. В Японском море были собраны особи, сходные морфологически с E. sanjuanensis. Тем не менее, предварительный молекулярный анализ показал их близкое родство к арктическому виду E. odhneri. Были получены новые данные по последовательностям митохондриальных (COI и $16 \mathrm{~S}$ рРНК), и ядерных (гистон $\mathrm{H} 3$ и $18 \mathrm{~S}$ рРНК) маркеров для реконструкции молекулярно-филогенетических отношений с применением методов Байесовского анализа и Максимального правдоподобия, анализов молекулярного разделения видов ASAP, bPTP и GMYC и оценки времен дивергенций предполагаемых видов. Также были изучены морфологические и экологические особенности, включая внешнюю морфологию, окраску, морфологию челюстей, радулы и половой системы, а также тонкое строение книдосаков и определение пищевых предпочтений. Наши результаты показывают, что особи из Японского моря представляют собой новый вид Eubranchus malakhovi sp.n. Он отличается как по морфологическим, так и по молекулярным данным от арктического вида E. odhneri и E. sanjuanensis, обитающего в северовосточной части Тихого Океана. Новый вид филогенетически близок к виду $E$. odhneri, с крайне невысокими отличиями по митохондриальной ДНК, и по нашим оценкам время дивергенции данных видов составляет 1,5 млн. лет назад.

Как цитировать эту статью: Ekimova I.A., Mikhlina A.L., Vorobyeva O.A., Antokhina T.I., Tambovtseva V.G., Schepetov D.M. Young but distinct: description of Eubranchus malakhovi sp.n. a new, recently diverged nudibranch species (Gastropoda: Heterobranchia) from the Sea of Japan // Invert. Zool. Vol.18. No.3. P.197-222, Table S1, Fig. S1, Data S1. doi: 10.15298/invertzool.18.3.02

КЛЮЧЕВЫЕ СЛОВА: Nudibranchia, Северо-Западная Пацифика, Арктика, разделение видов, молекулярная филогения, интегративная таксономия, Mollusca. 


\section{Introduction}

Eubranchus is a large genus of nudibranch molluscs within the family Fionidae (Cella et $a l ., 2016)$ with more than 50 species described up to date (MolluscaBase, 2021) and distributed worldwide (Burn, 1964; Edmunds, Kress, 1969; Cella et al., 2016). In boreal and Arctic waters species of Eubranchus represent quite abundant components of hydrozoan fouling communities (Roginskaya, 1987; Mikhlina et al., 2020). At the same time, modern taxonomical revisions and dedicated phylogenetic studies have not paid enough attention to this genus. During the last two decades only two contributions performed integration of morphological and molecular data within this group: (1) a recent revision of the family Fionidae (Cella $e t$ al., 2016) that evaluated Eubranchus as a member of this family and suggested that the amphiboreal Eubranchus rupium (Møller, 1842) represented a species complex of at least three distinct species; and (2) revision of the Eubranchus farrani (Alder et Hancock, 1844) - E. pallidus (Alder et Hancock, 1842) species complex (Korshunova et al., 2020) completed with a reinstatement of the generic name Amphorina for these molluscs and the description of two new species from the North-East Atlantic: Amphorina andra Korshunova et al., 2020 and $A$. viriola Korshunova et al., 2020. However, in this case no genetic differences were observed between these two new species, and their delimitation was based on ecological and bathymetric data as well as several minor morphological differences. Other boreal and Arctic Eubranchus species [e.g., Eubranchus alexeii (Martynov, 1998), E. exiguus (Alder et Hancock, 1848), E. horii Baba, 1960, E. odhneri (Derjugin et Gurjanova, 1926), E. sanjuanensis Roller, 1972, and others] have never been examined for presence of the cryptic diversity.

Boreal and Arctic fauna presents significant taxonomical challenge as speciation in these regions is affected by multitude of factors, that are not easy to estimate. In high latitudes environmental conditions have recently changed significantly (Layton et al., 2016). Glaciation cycles promote frequent opportunities for expansion to new ecological niches as communities are constantly changing (Clark, Crame, 2010). Glaciations also promoted geographic barriers formed and ceased to exist multiple times (Bowen et al., 2016; Loeza-Quintana, Adamowicz, 2018; Ekimova et al., 2019b), which lead to allopatric speciation events. Unlike in sympatric speciation, no ecological separation may happen, and truly cryptic species can form with overlapping morphological variation, but significant genetic distance. On the other hand, temporary isolation may lead to local populations acquiring distinct morphology, through random drift or local adaptation, but as soon as barriers fall, interbreeding resumes. These two types of cases represent major problems in species delimitation, as the same clades would be considered to be (or not) distinct species using different criteria (Knowlton, 2000; Avise, 2004).

Several specimens initially identified as the North-East Pacific species Eubranchus sanjuanensis were collected during fieldwork in the Sea of Japan, Rudnaya Bay in 2019. This species was described from British Columbia (Roller, 1972) and further its range was extended to Washington and Alaska (Millen, 1983, 1989). In the Sea of Japan, it was found by local diver Andrey Shpatak in 2014 and since then was commonly detected in the area. However, preliminary molecular data indicated that these animals were closer to the Arctic species Eubranchus odhneri. The latter species was described under the name Galvina odhneri from the Novaya Zemlya (Derjugin, Gurjanova, 1926), and then found in coastal waters of the Barents Sea and the White Sea (Roginskaya, 1987; Martynov et al., 2006). Eubranchus odhneri and newly discovered specimens demonstrated only minor genetic differences, suggesting this could be a case of either cryptic diversity or intraspecific polymorphism.

Therefore, this study is dedicated to integrative investigation of E. odhneri-E. sanjuanensis species complex, with a focus on specimens from the Arctic and the North-West Pacific. Specifically, we studied molecular data 


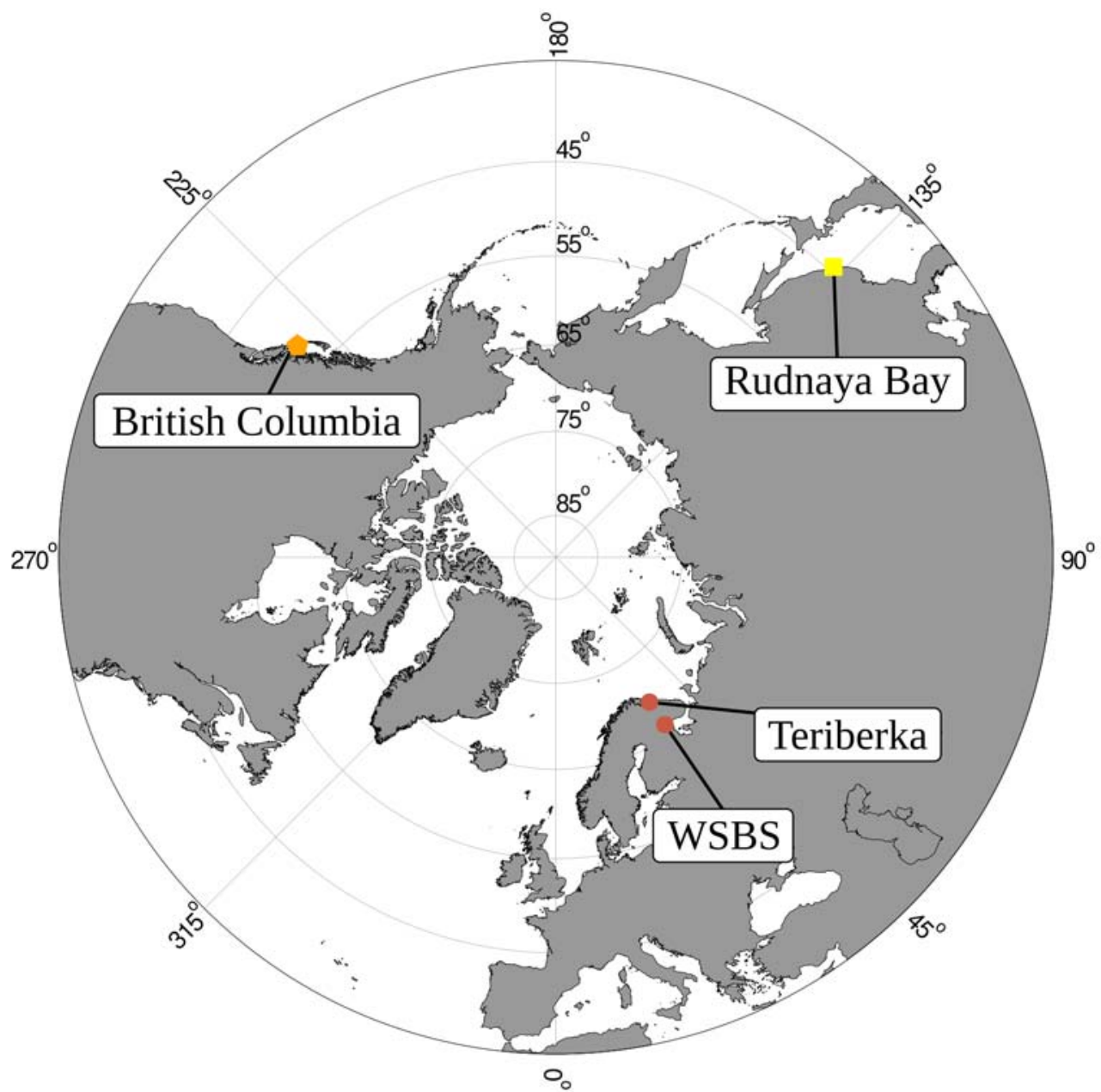

- E. odhneri E.malakhovi E. sanjuanensis

Fig. 1. Map of the Northern hemisphere showing collection localities of Eubranchus malakhovi sp.n. and Eubranchus odhneri. Collection locality for Eubranchus sanjuanensis from the GenBank is also shown. Рис. 1. Карта северного полушария, показаны места сбора Eubranchus malakhovi sp.n. и Eubranchus odhneri. Также показано место сбора Eubranchus sanjuanensis из базы данных GenBank.

of mtDNA and nDNA gene fragments using a variety of automated species delimitation methods, and observe morphological diversity and ecological features.

\section{Material and methods}

COLLECTION DATA. Specimens used in this study were collected in the three localities: (1) the Sea of Japan, Rudnaya Bay; (2) the
White Sea, in the vicinity of the White Sea Biological Station, MSU and (3) the Barents Sea, Teriberka Bay (Fig. 1). All samples were collected by SCUBA diving at depths of 2-30 m on hard substrates or in tidal areas. All specimens were photographed and fixed in 96\% ethanol for morphological and molecular studies. In addition, cerata of several specimens were dissected before fixation and then preserved in $2.5 \%$ glutaraldehyde for the study of 
cnidosac ultrastructure. Voucher specimens are deposited in the collections of the National Scientific Centre of Marine Biology, Far Eastern Branch RAS. The new species was registered in ZooBank [lsid of the publication is: urn:lsid: zoobank.org:pub:429B8BEE-58A4-46D69F42-2156E6D2352D]. Details of sampling localities and voucher numbers for each specimen are given in Table S1.

TAXON SAMPLING AND FOLLOWED TAXONOMICAL SCHEME. For phylogenetic reconstruction datasets for the genus Eubranchus obtained in previous studies were incorporated in the analyses (Cella et al., 2016; Korshunova et al., 2020) as well as several additional sequences from GenBank (Table S1). Representatives of the genera Abronica and Cuthona were chosen as outgroups (Cella et al., 2016). Recently the genus Amphorina was established for five North-East Atlantic Eubranchus species, however on some reconstructions (i.e. Cella et al., 2016; Korshunova et al., 2020) the type Eubranchus species E. tricolor is sister to the "Amphorina" clade, which clearly makes the genus Eubranchus a paraphyletic one, but no solution had been proposed (Korshunova et al., 2020). Therefore, due to overall poorly supported phylogeny and possible confusion with Eubranchus monophyly we suggest to follow a stable version of Fionidae taxonomy, e.g. the taxonomic decision considering a single genus Eubranchus (Cella et al., 2016; Korshunova et al., 2017) until the dedicated revision would be conducted.

DNA EXTRACTION, AMPLIFICATION, SEQUENCING. DNA was extracted from small pieces of foot muscle tissue using a PALLTM AcroPrep 96-well purification plates by $P A L L$ Corp., following a protocol by Ivanova et al. (2006). Obtained DNA samples were used as a template for amplification of partial cytochrome $c$ oxidase subunit I (COI) (estimated length $\sim 658 \mathrm{bp}), 16 \mathrm{~S}$ rRNA ( 450 bp), histone H3 $(\sim 350 \mathrm{bp})$ and $18 \mathrm{~S}$ (in three parts, $\sim 1865 \mathrm{bp}$ overall). Primers used for amplification and sequencing, and amplification conditions are shown in Table 1. Polymerase chain reaction were carried out in a $25-\mu \mathrm{L}$ reaction volume ( 5 $\mu \mathrm{L}$ of $5 \times$ HotTaq buffer Eurogen Lab, $0.5 \mu \mathrm{L}$ of HotTaq polimerase Eurogen Lab, $0.5 \mu \mathrm{L}$ of each primer (10 $\mu \mathrm{M}$ stock), $1 \mu \mathrm{L}$ of genomic DNA and $17.4 \mu \mathrm{L}$ of sterile water). Both strands of each amplicon were sequienced with the BigDye Terminator v3.1 sequencing kit by Applied Biosystems. Sequencing reactions were analyzed by capillary electrophoresis on ABI 3500 Genetic Analyser or ABI 3130 Genetic Analyser (Applied Biosystems) at the N.K. Koltsov Institute of Developmental Biology or the Lomonosov Moscow State University (Moscow, Russia). All new sequences were deposited at the GenBank public database (Table S1). Raw reads for each gene were assembled and checked for improper base-calling (those sites were further modified) using GeneiousPro 4.8.5 (Biomatters, Auckland, New Zealand).

DATA PROCESSING AND PHYLOGENETIC ANALYSES. Original data and publicly available sequences were aligned with the MUSCLE (Edgar, 2004) algorithm implemented in GeneiousPro 4.8.5. Protein-coding sequences were translated into amino acids to eliminate possible pseudogenes by verifying CDS reading frame integrity. No pseudogenes were detected. The resulting alignments were of $660 \mathrm{bp}$ for COI, $461 \mathrm{bp}$ for $16 \mathrm{~S}, 327 \mathrm{bp}$ for H3 and $1863 \mathrm{bp}$ for $18 \mathrm{~S}$. Manual inspection did not detect indel-rich regions in the dataset and therefore our analysis included all positions. Phylogenetic analysis was conducted for all datasets concatenated and for the COI gene individually. Sequences were concatenated by a simple Biopython script (Chaban et al., 2019). The bestfitting nucleotide evolution model was tested in the Modeltest-NG (Darriba et al., 2020) toolkit based on the Bayesian information criterion (BIC) for each partition. The best-fitting model for the COI partition was $\mathrm{HKY}+\mathrm{G}+\mathrm{I}$, for $16 \mathrm{~S}$ partition was GTR $+\mathrm{G}+\mathrm{I}$, and for both $18 \mathrm{~S}$ and $\mathrm{H} 3$ it was K2+G. Phylogenetic reconstructions were performed by Bayesian estimation of posterior probability and Maximum likelihoodbased phylogeny inference. The Bayesian estimation of posterior probability was performed in MrBayes 3.2.7a (Ronquist, Huelsenbeck, 2003) applying evolutionary models for parti- 


\begin{tabular}{|c|c|c|c|c|}
\hline 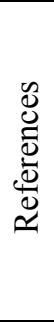 & 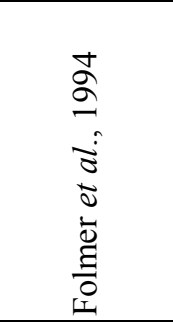 & 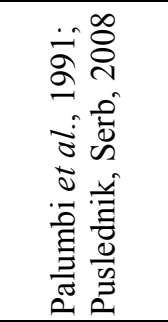 & 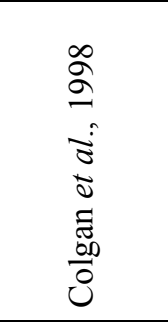 & 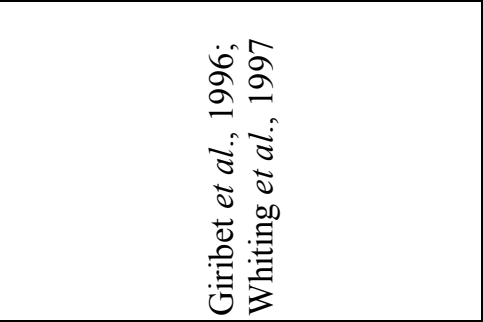 \\
\hline 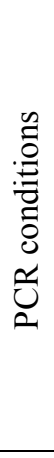 & 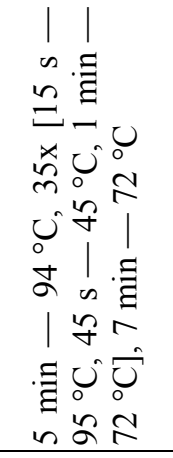 & 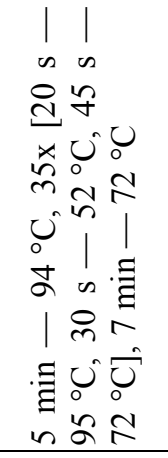 & 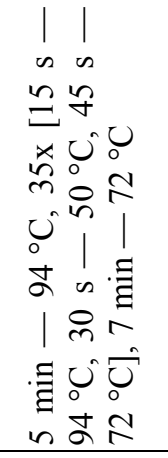 & 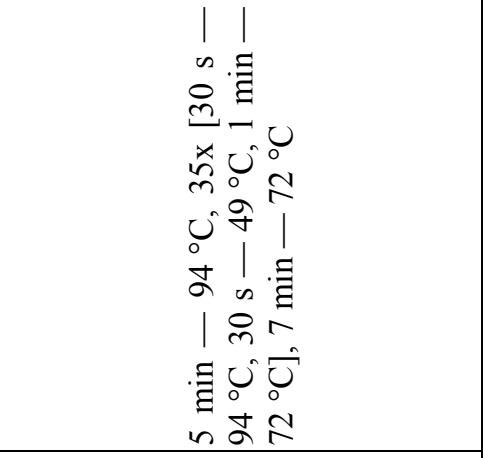 \\
\hline 离 & 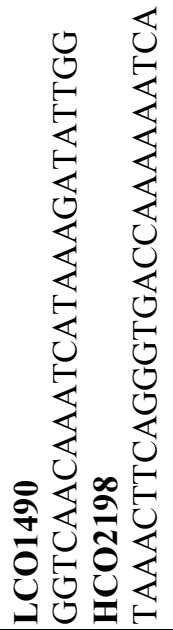 & 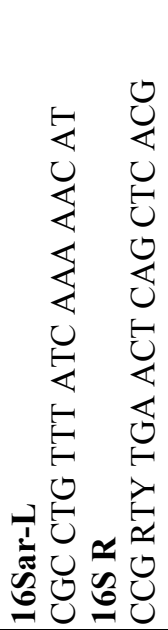 & 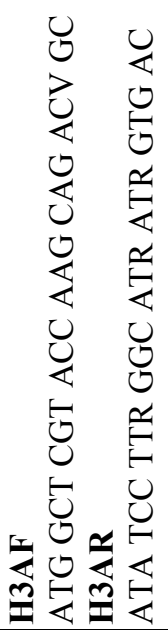 & 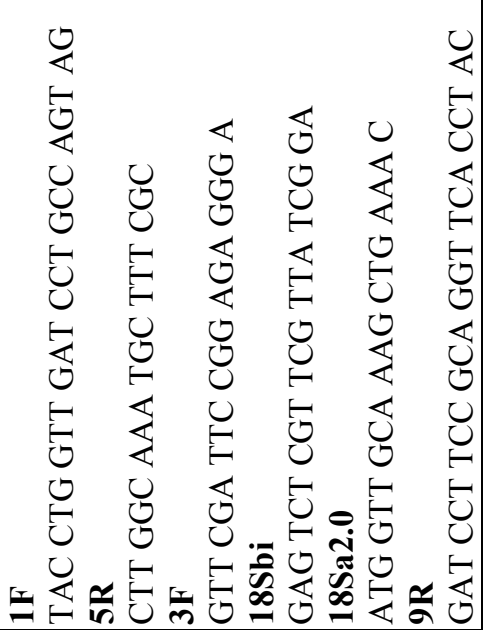 \\
\hline 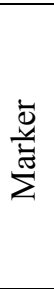 & 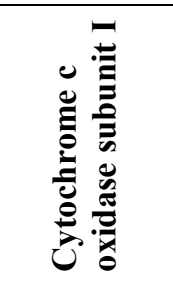 & $\begin{array}{l}\mathbb{Z} \\
\mathbb{Z} \\
\mathbb{Z}\end{array}$ & 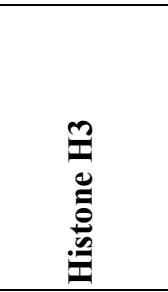 & $\begin{array}{l}\overleftrightarrow{Z} \\
\stackrel{2}{\mid} \\
\infty \\
\infty\end{array}$ \\
\hline
\end{tabular}


tions separately. Maximum likelihood-based phylogeny inference was performed with the HPC-PTHREADS version of RaxML v.8.2.12 (Stamatakis, 2014) with ultrafast bootstrapping (UFBoot approximation approach) (Minh et al., 2013) in 1000 pseudoreplicates under the GTRCAT model of nucleotide evolution, applied to partitions individually. Resulting phylogenetic tree graphs were rendered in FigTree 1.4.4 and their visual component was further modified in Adobe Illustrator CC 2015. The posterior probabilities from Bayesian Inferences (PP) higher than 0.99 and bootstrap support from the Maximum Likelihood (BS) higher than 90\% were designated as "high"; PP from 0.95 to 0.98 and BS from 75 to $89 \%$ indicate moderate support; PP from 0.9 to 0.94 and BS from 60 to $74 \%$ indicate low support. Branches that received lower support were interpreted as unsupported.

SPECIES DELIMITATION ANALYSES. The COI alignment was used for computational species delimitations methods. $P$-distances were calculated using MEGA7 software (Kumar et al., 2016). To confirm the status of the clades recovered in our analysis as putative species we used the Assemble Species by Automatic Partitioning (ASAP) method (Puillandre et al., 2021) to detect breaks in the distribution of intra- and interspecific distances without any prior species hypothesis, referred to as the "barcode gap" (Herbert et al., 2003). The ASAP analysis was run on the online version of the program (https:/ /bioinfo.mnhn.fr/abi/public/asap/asapweb.html) with three proposed models - Jukes-Cantor (JC69), Kimura (K80) and Simple distance. It was complemented by Poisson Tree Processes (PTP) (Zhang et al., 2013), which is based on a phylogenetic species concept assumption, and thus implements Bayesian MCMC methods to find the groups descent from a single ancestor (i.e. phylogenetic species) using a previously inferred phylogenetic tree. The test was run using the bPTP Server http://species.h-its.org/ ptp/ with 500000 generations and with other settings set as default with COI-based Maximum likelihood tree as input. Additionally, we performed a GMYC test (Pons et al., 2006) and implemented by Fujisawa and Barraclough
(2013). Approaches based on the GMYC model rely on the expectation that intraspecific coalescent branching proceeds discernibly quicker than speciation, which is modelled as a Yule process. It requires a fully dichotomous and rooted ultrametric tree without duplicate sequences based on single-gene analyses. The COI-based ultrametric tree was calculated using BEAST 2.6.4 (Bouckaert et al., 2019) with $10^{7}$ generations and then analyzed in the $\mathrm{R}$ environment (package splits), following instructions by Fujisawa \& Barraclough (2013). Finally, to confirm that putative species, recovered in delimitation analyses based on mtDNA, also show divergence in nDNA, the $18 \mathrm{~S}$ alignment was inspected for phylogenetically important species-specific substitutions.

HAPLOTYPE NETWORKS. Population study was based on the COI sequences, including original sequences and those retrieved from the GenBank (Table S1). Haplotype networks were constructed using PopArt software (http:/ /popart.otago.ac.nz)(Leigh, Bryant, 2015) with the TCS network method (Clement et al., 2002). Final output networks were edited in Adobe Illustrator CC 2015.

NODE DATING. We used outgroup-based existing secondary calibrations and general geology-based calibration principles as implemented in Ekimova et al. (2019b), as no fossil-based calibrations are available for fionid nudibranchs. For the estimation we used recently published secondary estimates for the genus Dendronotus with three calibration points: (1) D. lacteus (Thompson, 1840)/D. rufus O'Donoghue, 1921 - 2 Mya; (2) D. frondosus (Ascanius, 1774) / D. primorjensis Martynov et al., $2015-3$ Mya; and (3) D. dalli Bergh, 1879 / D. niveus Ekimova et al., 2015 - 3.5 Mya, following Ekimova et al. (2019b). The analysis was performed in BEAST v. 2.4.4 (Bouckaert et al., 2019). The relaxed uncorrelated lognormal clock model was implemented to allow the rate on each branch be independently drawn from a lognormal distribution with a calibrated Birth-Death model. Analyses were conducted with 10 million generations and a sampling frequency of 1000 , with a burn-in of $25 \%$ of the trees generated. 
MORPHOLOGICAL STUDIES. All collected specimens were used for the study of external morphology under a stereomicroscope Olympus SZ51. For the internal morphology (jaws, radula, reproductive system and cnidosac ultrastructure) at least three specimens per species were studied to test for possible intraspecific variation. The buccal mass of each specimen was extracted and soaked in proteinase $\mathrm{K}$ solution for 2 hours at $60{ }^{\circ} \mathrm{C}$ to dissolve soft tissues. The radula and the jaws were rinsed in distilled water, air-dried, mounted on an aluminium stub, and sputter-coated with gold. Features of the jaws of each specimen were analysed by optical stereomicroscopy and scanning electron microscopy (SEM) with CamScan S2 and JEOL JSM 6380 scanning electron microscopes. The radulae were examined and photographed using SEM, and the reproductive systems were examined under a stereomicroscope. Cerata of specimens from different localities were dissected, fixed in $2.5 \%$ glutaraldehyde with Millonig's phosphatic buffer (pH 7.4) (Millonig, 1964), then rinsed in the same buffer. A postfixation was performed using $1 \% \mathrm{OsO}_{4}$ buffered in Millonig's phosphatic buffer for $1.5 \mathrm{~h}$ in the dark, after which samples were rinsed in the same buffer. Then cerata were dehydrated in graded ethanol and acetone solutions and embedded in Epon 812 resin. Twelve series of ultra-thin sections $(80 \mathrm{~nm})$ were prepared with a Leica EM UC6 ultramicrotome using a diamond knife Ultra $45^{\circ}$ (Diatome, Switzerland). The sections were stained with uranyl acetate $(1 \%, 40 \mathrm{~min}$, $37^{\circ} \mathrm{C}$ ) and lead citrate (10 min, in the dark). The sections were analyzed using a Jeol JEM-1011 transmission electron microscope (TEM).

\section{Results}

MOLECULAR PHYLOGENETIC ANALYSIS. Trees based on the single-gene analyses were poorly resolved (Data S1), however the concatenated tree provided good resolution for most clades (Fig. 2). The topology of the concatenated trees generated with Bayesian Inference (BI) and maximum likelihood (ML) analyses were congruent in most cases, except basal relationships within Eubranchus. In our analysis the genus Eubranchus was recovered as monophyletic, however with no statistical support $(\mathrm{PP}=0.55$; $\mathrm{BS}=48)$. The studied specimens clustered with Eubranchus sanjuanensis from British Columbia and together formed a monophyletic clade (PP = 1; BS = 100). Within this clade, specimens from the Sea of Japan form a single supported group ( $\mathrm{PP}=0.98 ; \mathrm{BS}=$ 74), which is sister to Eubranchus odhneri from the White and the Barents seas ( $\mathrm{PP}=1$; $\mathrm{BS}=$ 93).

POPULATION STRUCTURE. In the COIbased TCS haplotype network (Fig. 3A), studied specimens formed two haplogroups separated by 12 substitutions: (1) White Sea and Barents Sea specimens, (2) specimens from the Sea of Japan. Eubranchus sanjuanensis formed a separate haplotype, differing in 29 substitutions from haplogroup 2.

SPECIES DELIMITATION. Three monophyletic units recovered in the phylogenetic analysis (specimens from the Arctic and the NW Pacific, the NE Pacific E. sanjuanensis) were identified as candidate species in the species delimitation analyses (Fig. 3B). Minimum interspecific and maximum intraspecific distances are shown in Table 2. The ASAP analysis showed lowest ASAP score (2.5) for 16 groups for entire alignment, but specimens from the Arctic and the NW Pacific were placed in a single group, as well as Eubranchus sp. from Spain and E. vittatus. Iteration with 18 species groups corresponding putative candidate species received higher ASAP score (5.0) as interspecific distances value was below the barcode gap threshold. The bPTP analysis revealed 7 candidate species for studied species complex. The GMYC analysis recovered same groups as putative candidate species. Finally, three candidate species differed by three substitutions in the 18S dataset (positions 688-690). Overall, bPTP and ASAP failed to delimit studied specimens, suggesting oversplitting (bPTP) or overlumping (ASAP) delimitation schemes, possibly due to lower substitution rates in the COI marker compared to other Eubranchus species (see discussion). However, taking into account 


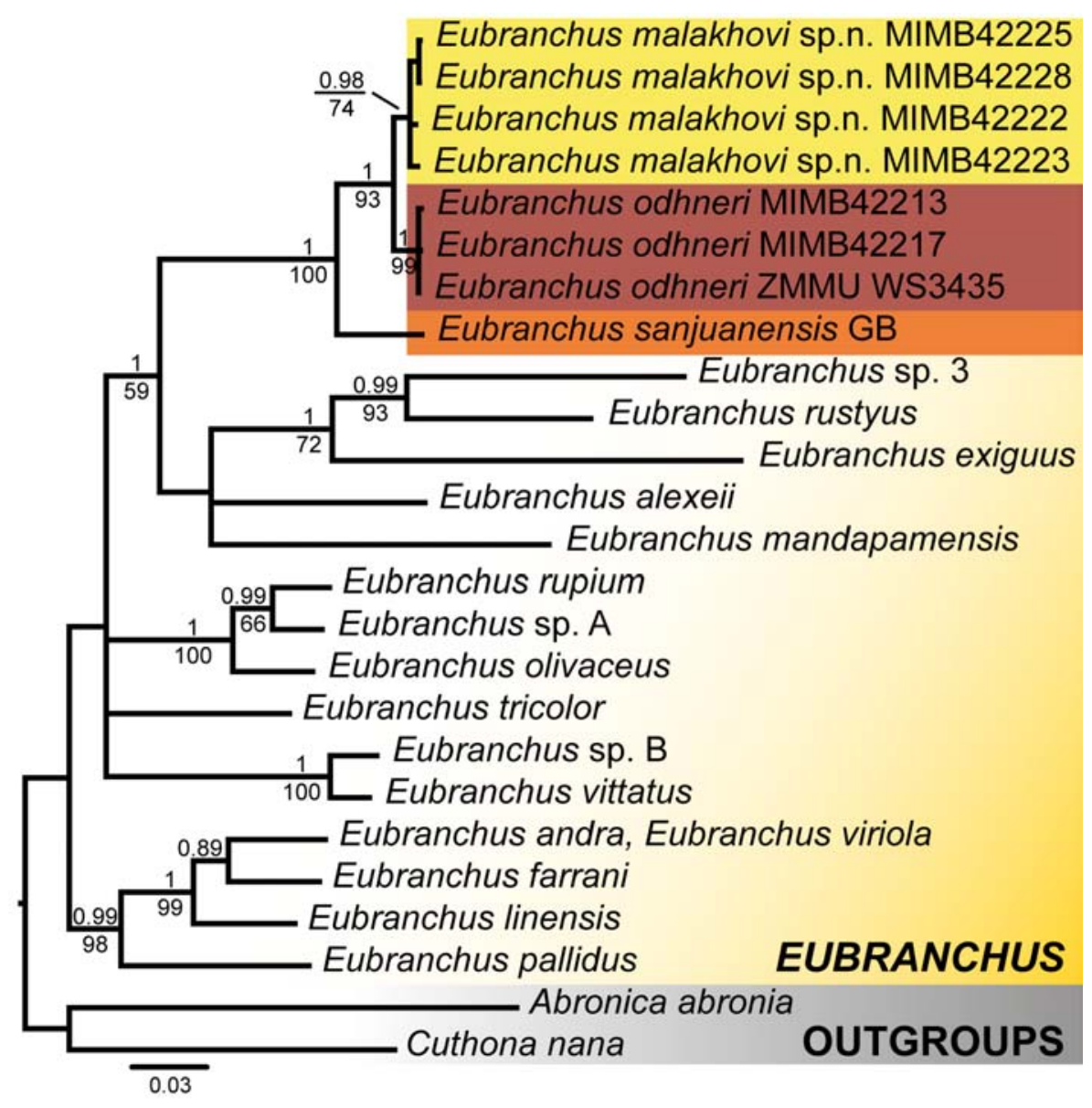

Fig. 2. Molecular phylogenetic reconstruction of the genus Eubranchus based on the concatenated dataset $(\mathrm{COI}+16 \mathrm{~S}+\mathrm{H} 3+18 \mathrm{~S})$, Bayesian inference. Species-level clades and outgroups are collapsed to a single branch, except the target species. Eubranchus andra and Eubranchus viriola do not form two separated monophyletic units and are shown as members of a single clade. Numbers above branches indicate posterior probabilities (PP) from Bayesian Inference, numbers below branches — bootstrap support from Maximum Likelihood (BS). Only PP $>0.9$ and $\mathrm{BS}>60$ are shown.

Рис. 2. Реконструкция молекулярно-филогенетических отношений рода Eubranchus, построенная по данным комбинированного датасета $(\mathrm{COI}+16 \mathrm{~S}+\mathrm{H} 3+18 \mathrm{~S})$ с применением Байесовского анализа. Аутгруппы и клады видового уровня, за исключением исследуемых видов, сколлапсированы до одной особи на вид. Eubranchus andra и Eubranchus viriola не образуют два монофилетичных юнита и показаны в составе единой клады. Цифры над ветвями обозначают апостериорные вероятности (PР) Байесовского анализа, цифры под ветвями — бутстреп-поддержки (BS) метода Максимального правдоподобия. Показаны только значения $\mathrm{PP}>0,9$ и $\mathrm{BS}>60$.

the GMYC results and the differences found in an independent nuclear marker $(18 \mathrm{~S})$ in addition to the divergence observed in COI, we suggest that the NW Pacific specimens represent a new distinct species, and its formal taxonomical description is provided below.
DIVERGENCE TIME ESTIMATION. The calibrated ultrametric tree is represented in Fig. 4. It suggests the diversification of E. sanjuanensis, the Arctic species E. odhneri and the new species from the NW Pacific to have taken place during the late Miocene-Pliocene. TMRCA of 
A
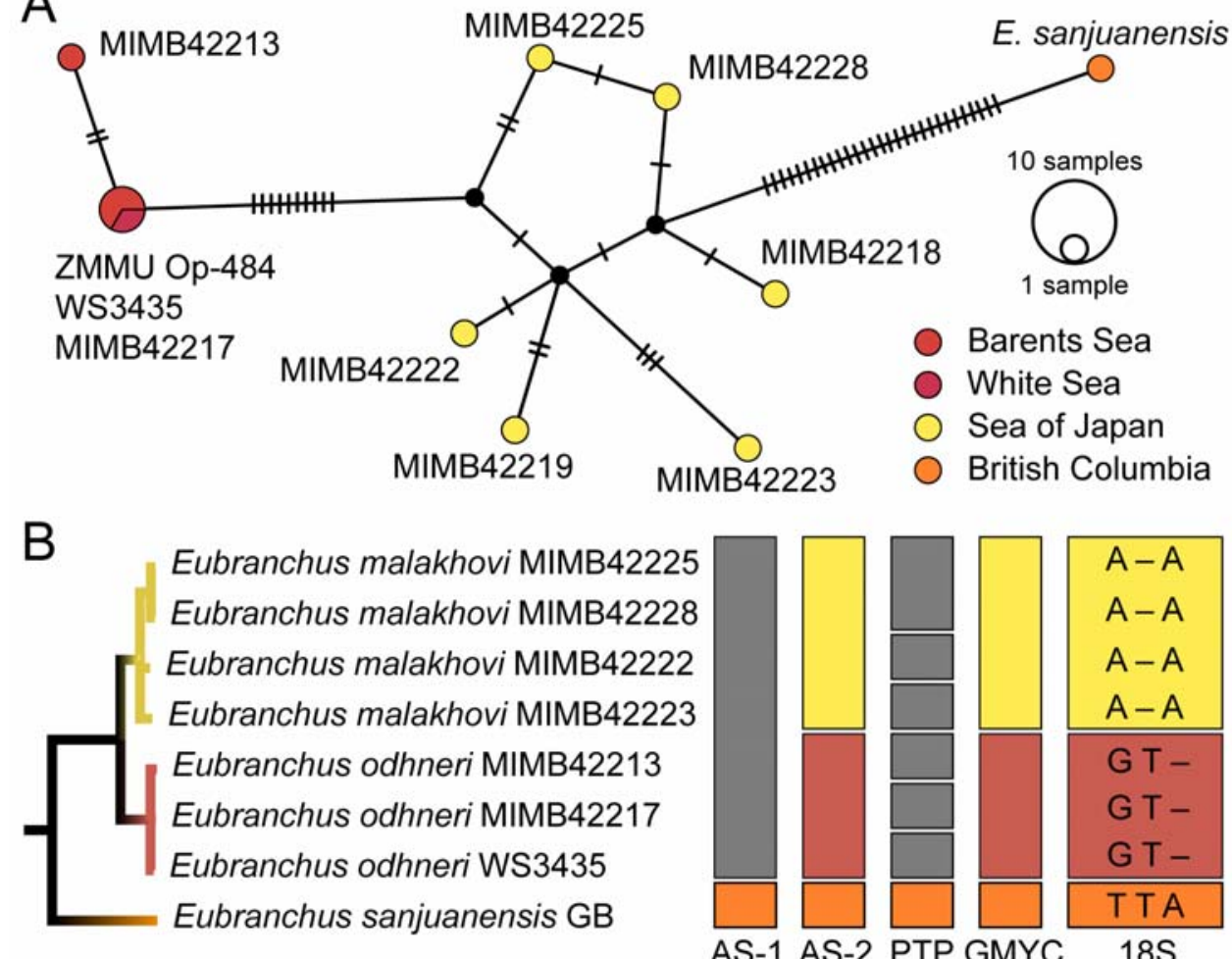

Fig. 3. Species delimitation for target Eubranchus species. A - COI haplotype network produced with TCS method in PopART. Color of circles refers to the geographic origin of each haplotype. The relative size of circles is proportional to the number of sequences of that same haplotype. B - results of species delimitation analyses. Abbreviations: AS1 - Assemble Species by Automatic Partitioning, value 2.0; AS2 - Assemble Species by Automatic Partitioning, value 5.0; PTP - poisson tree process; GMYC — general mixed YuleCoalescent analysis; $18 \mathrm{~S}$ - differences found in 18S dataset, positions 688-690 (total length $1863 \mathrm{bp}$ ). Рис. 3. Анализы молекулярного разделения видов для исследуемых представителей рода Eubranchus. A - сеть гаплотипов по маркеру COI, построенная с помощью метода TCS в пакете программы PopART. Цвет кругов обозначает принадлежность каждого гаплотипа к определенному географическому локалитету. Относительный размер кругов пропорционален количеству сиквенсов соответствующих одному гаплотипу. В - результаты делимитационного анализа. Обозначения: AS-1 выделение видов автоматическим разделением (ASAP), значение 2,0; AS-2 - выделение видов автоматическим разделением (ASAP), значение 5,0; РТP - пуассоновское процессирование дерева; GMYC - генерализированный смешанный анализ коалесцентной модели Юля; $18 \mathrm{~S}$ - показаны различия в 18S датасете, позиции 688-690 (общая длина 1863 п.н.).

Table 2. Uncorrected range interspecific (regular font) and maximum intraspecific (bold) $p$-distances calculated in MEGA7 for three candidate Eubranchus species included in this study (in \%).

Таблица 2. Нескорректированные минимальные и максимальные межвидовые (обычный шрифт) и максимальные внутривидовые (полужирный шрифт) $p$-дистации, посчитанные в программе MEGA7 для трех видов Eubranchus включенных в данное исследование (в \%).

\begin{tabular}{|l|c|c|c|}
\hline & $\begin{array}{c}\text { Eubranchus } \\
\text { malakhovi sp.n. }\end{array}$ & $\begin{array}{c}\text { Eubranchus } \\
\text { odhneri }\end{array}$ & $\begin{array}{c}\text { Eubranchus } \\
\text { sanjuanensis }\end{array}$ \\
\hline Eubranchus malakhovi sp.n. & $\mathbf{1 . 1 3}$ & & \\
\hline Eubranchus odhneri & $2.48-3.38$ & $\mathbf{0 . 4 5}$ & \\
\hline Eubranchus sanjuanensis & $6.53-7.43$ & 7.88 & $\mathbf{n} / \mathbf{a}$ \\
\hline
\end{tabular}




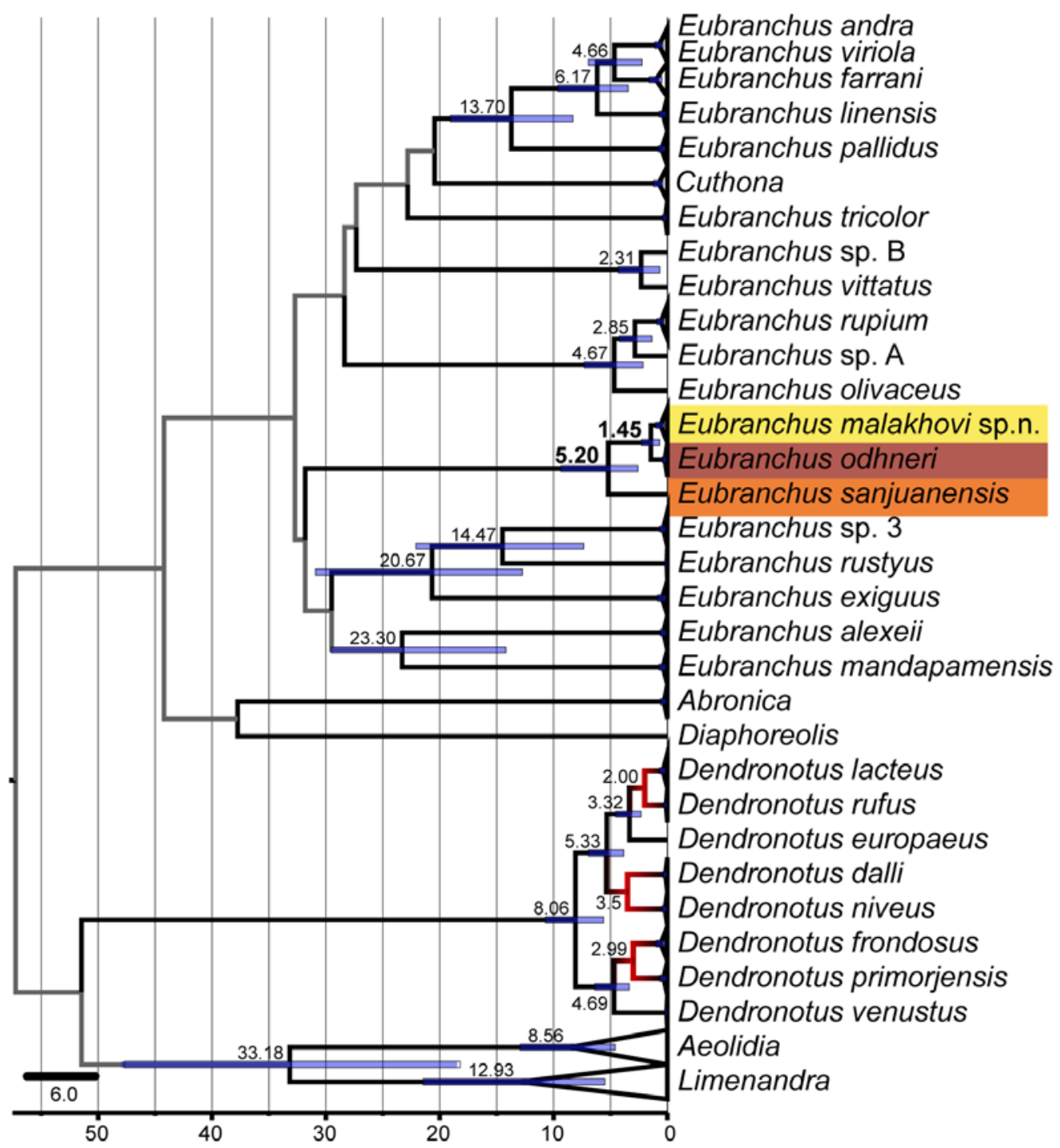

Fig. 4. Chronogram of divergence times in the genus Eubranchus obtained using BEAST software. Divergence time estimates are displayed on respective supported node (in Mya). The molecular clock was calibrated using the closure of the Bering Strait (red branches), based on the Iterative calibration approach from Ekimova et al. (2019b). Grey branches indicate unsupported relationships. Species-level clades and outgroups are collapsed to a single branch, except the target species. Eubranchus andra and Eubranchus viriola do not form two separated monophyletic units and are shown as members of a single clade.

Рис. 4. Хронограмма времени дивергенции видов рода Eubranchus, полученная в пакете программы BEAST. Оценка времени разделения видов показана в соответствующих поддержанных узлах (в млн.л.н.). Молекулярные часы были откалиброваны по датировкам закрытия Берингова пролива (красные узлы), на основании итеративного калибровочного подхода (Ekimova et al., 2019b). Серые ветви обозначают неподдержанные филогенетические отношения. Аутгруппы и клады видового уровня, за исключением исследуемых видов, сколлапсированы до одной особи на вид. Eubranchus andra и Eubranchus viriola не образуют два монофилетичных юнита и показаны в составе единой клады. 
E. odhneri and the new species from the NW Pacific is 1.45 Mya.

\section{Systematics}

Order Nudibranchia
Suborder Cladobranchia
Superfamily Fionoidea
Family Fionidae sensu Cella et al., 2016
Eubranchus odhneri (Derjugin et Gurjanova,
1926)
Figs 5, 6, 7A, B, 8A, 9.

TYPE MATERIAL. Lost.

TYPE LOCATION. Novaya Zemlya, Barents Sea.

MATERIAL EXAMINED. ZMMU WS3435, 1 specimen, tissue sample, White Sea, Velikaya Salma Strait, Velikiy Is., $11-15 \mathrm{~m}$ in depth, 10.06.2013, coll. A. Semenov. MIMB 42213, 1 specimen, dissected, L (length) $=17$ $\mathrm{mm}$, Barents Sea, Teriberka Bay, $69^{\circ} 11.085^{\prime} \mathrm{N}$ $35^{\circ} 07.895^{\prime} \mathrm{E}, 10 \mathrm{~m}$ in depth, 13.05.2019, coll. T. Antokhina. MIMB 42214, 1 specimen, dissected, $\mathrm{L}=20 \mathrm{~mm}$, Barents Sea, Teriberka Bay, $69^{\circ} 11.407^{\prime} \mathrm{N} 35^{\circ} 08.221^{\prime} \mathrm{E}, 5-20 \mathrm{~m}$ in depth, 14.06.2020, coll. T. Antokhina. MIMB 42217, 1 specimen, dissected, $\mathrm{L}=16 \mathrm{~mm}$, Barents Sea, Teriberka Bay, $69^{\circ} 11.407^{\prime} \mathrm{N} 35^{\circ} 08.221^{\prime} \mathrm{E}$, 5$20 \mathrm{~m}$ in depth, 12.06.2020, coll. T. Antokhina. MIMB 42215, 1 specimen, $\mathrm{L}=14 \mathrm{~mm}$, dissected, Barents Sea, Teriberka Bay, $69^{\circ} 11.407^{\prime} \mathrm{N}$ $35^{\circ} 08.221^{\prime} \mathrm{E}, 5-25 \mathrm{~m}$ in depth, 16.06.2020, coll. T. Antokhina. MIMB 42216, 1 specimen, dissected, $\mathrm{L}=15 \mathrm{~mm}$, Barents Sea, Teriberka Bay, $69^{\circ} 11.407^{\prime} \mathrm{N} 35^{\circ} 08.221^{\prime} \mathrm{E}, 5-25 \mathrm{~m}$ in depth, 16.06.2020, coll. T. Antokhina.

EXTERNAL MORPHOLOGY. Length up to $20 \mathrm{~mm}$. Body elongate, narrow. Cerata arranged in up to seven distinct rows, with up to five cerata per row. Dorsal cerata swollen, digestive gland occupies up to $20 \%$ of their volume. Lateral cerata tubular, digestive gland diverticula occupy almost all internal space. Oral tentacles and rhinophores simple, elongated. Rhinophores longer than oral tentacles, smooth. Reproductive opening located laterally under second ceratal row at right. Anal opening acleioproctic, behind first three ceratal rows at right.

COLOURATION. Background color translucent-white. Rhinophores translucent. Digestive gland diverticula from pale brownish orange to red and clearly seen through translucent ceratal wall. Cnidosac areas marked with apical white pigmented caps (Fig. 5).

ANATOMY. Paired jaws triangle-shaped, thin and delicate, masticatory border of jaw with up to 10 distinct denticles (Fig. 6A, B). Radular formula 54-58 $\times$ 1.1.1. Rachidian teeth with slightly compressed conical cusps and 4-5 large denticles on each side. Lateral teeth triangle wide plates, thin and delicate, with triangle attenuated process in inner top. Length to width of lateral teeth ratio varies from 1:2 to 1:4 (Figs 6C-E; 7B).

Digestive gland with three main branches (right and left anterior and posterior), diverticula entering into cnidosacs, occupying each ceras top. Cnidosacs oval, with distinct proliferation and cnidophage zones. Cnidosac musculature thin-walled with indistinct layers. Cnidophages large cells, containing numerous small nematocysts in granular part of cytoplasm, rest cytoplasm electron-transparent. Distinct digestive vacuoles surrounding nematocysts. Haemocoel contains numerous amoebocytes. Epithelial cells with numerous vacuoles containing chitinous spindles, large mucous cells with electron-transparent compounds and specific cells with rounded electron-dense discs (Figs 8A; 9).

Reproductive system diaulic. Ampulla small bean-shaped sac. Prostatic vas deferens distinct, muscular, convoluted by midline, expanding into muscular penial sac. Penial gland present, inserting into penial base. Penial stylet present, short. Receptaculum seminis large muscular, with indistinct grooves where connected to vagina (Fig. 7A).

GEOGRAPHIC RANGE. Barents Sea (Derjugin, Gurjanova, 1926; Martynov et al., 2006; present study), White Sea (Roginskaya, 1987; present study), Norway (Bergh, 1886).

BIOLOGY. This species was found on different hydrozoans, including Sertulariidae spe- 

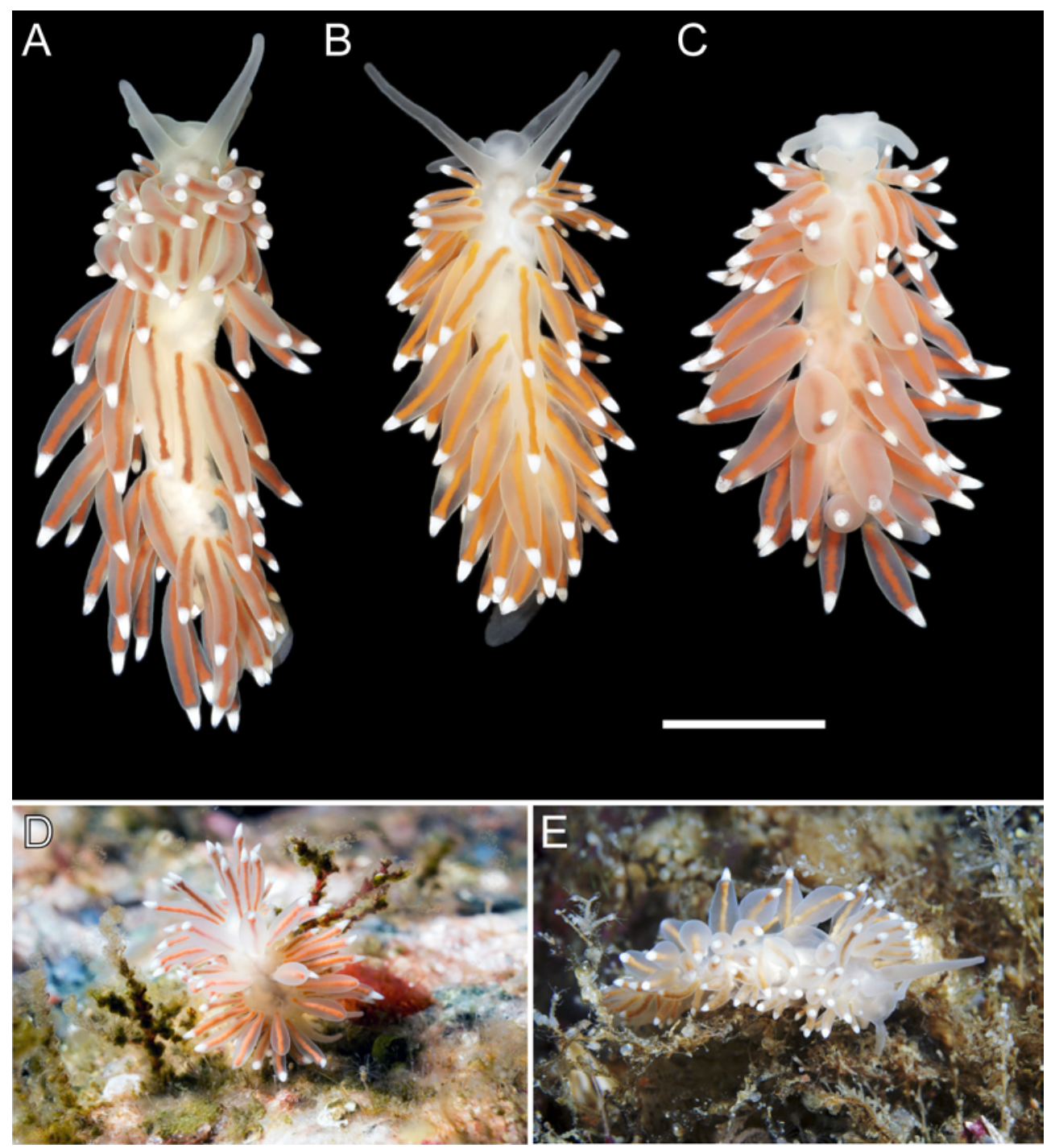

Fig. 5. Eubranchus odhneri, living specimens. A - MIMB42214; B - MIMB42217; C - MIMB42215; D - MIMB42213, living specimen in natural environment on unidentified sertulariid colony; E - ZMMU WS3435, living specimen in natural environment on unidentified sertulariid colony. Scale bar $5 \mathrm{~mm}$.

Рис. 5. Eubranchus odhneri, прижизненные фотографии. А - MIMB42214; В — MIMB42217; C MIMB42215; D - MIMB42213, живой представитель в естественной среде обитания на неопределенной колонии сертуляриидных гидроидов; E - ZMMU WS3435, живой представитель в естественной среде обитания на неопределенной колонии сертуляриидных гидроидов. Масштаб 5 мм.

cies (Fig. 5D, E). Egg mass a single-coiled spiral.

REMARKS. This species differs from its closer relatives (E. malakhovi sp.n. and E. san- juanensis) by its larger body size, radular morphology and minor differences in colouration, cnidosac structure and reproductive system (for details see Remarks section in E. malakhovi sp.n. description). 

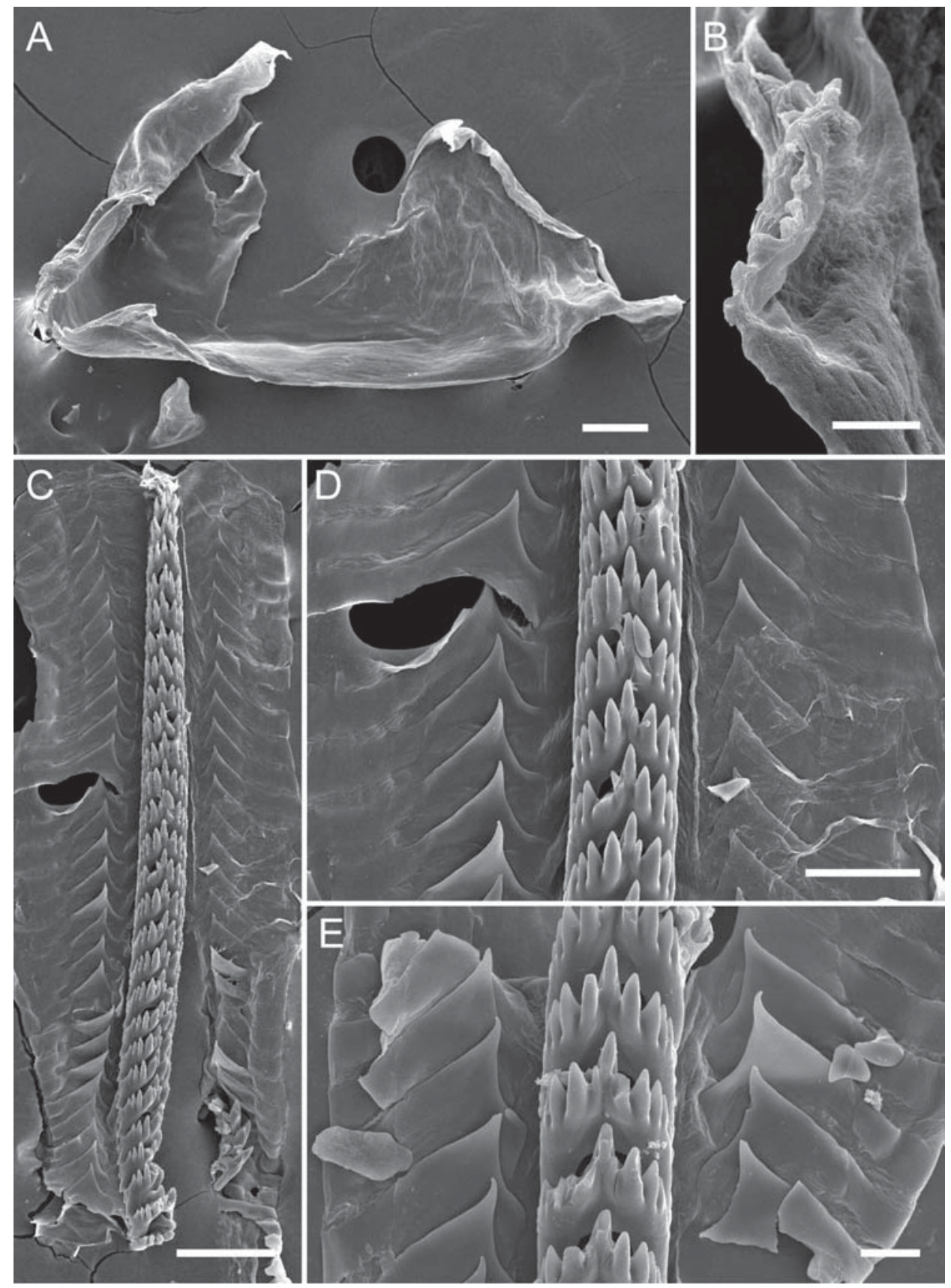

Fig. 6. Buccal armature in Eubranchus odhneri, SEM. A - MIMB42216, right jaw plate; B - MIMB42217, details of masticatory border denticulation; C - MIMB42217, radula; D - MIMB42217, rachidian and lateral teeth, middle radular portion; E - MIMB42216, rachidian and lateral teeth, middle radular portion. Scale bars: A, C $-100 \mu \mathrm{m}$; B, E $-20 \mu \mathrm{m}$; D $-50 \mu \mathrm{m}$.

Рис. 6. Буккальное вооружение Eubranchus odhneri, СЭМ. А - МIMB42216, правая челюстная пластинка; В - MIMB42217, детали зазубренности жевательного отростка; C — MIMB42217, радула; D MIMB42217, центральные и латеральные зубы, средняя часть радулы; E - MIMB42216, центральные и латеральные зубы, средняя часть радулы. Масштаб: А, C - $100 \mu \mathrm{m} ; \mathrm{B}, \mathrm{E}-20 \mu \mathrm{m} ; \mathrm{D}-50 \mu \mathrm{m}$. 


\section{Eubranchus malakhovi sp.n. urn:1sid:zoobank.org:act:BA5511B3-C9A1- 4CD9-A17C-D2088BFA5CD8 \\ Figs 7C, E, F, 8B, 10-12.}

TYPE MATERIAL. Holotype MIMB 42219, L $=5 \mathrm{~mm}$, North-West Pacific, Sea of Japan, Rudnaya Bay, $44^{\circ} 28.550^{\prime} \mathrm{N} 136^{\circ} 06.523^{\prime}$ E, 15-20 $\mathrm{m}$ in depth, 24.07.2020, coll. T. Antokhina, Yu. Deart. Paratypes: MIMB 42218, 1 specimen, dissected, $\mathrm{L}=5 \mathrm{~mm}$, locality, date and collectors same as MIMB 42219. MIMB 42220, 1 specimen, $\mathrm{L}=4 \mathrm{~mm}$, locality, date and collectors same as MIMB 42219.

TYPELOCALITY. North-West Pacific, Sea of Japan, Rudnaya Bay, $44^{\circ} 28.550^{\prime} \mathrm{N} 136^{\circ} 06$. 523'E, 15-20 $\mathrm{m}$ in depth.

ADDITIONAL MATERIAL EXAMINED. MIMB 42221-42223, 3 specimens, 2 dissected, $\mathrm{L}=4-6 \mathrm{~mm}$, locality, date and collectors same as MIMB 42219. MIMB 42224-42228, 5 specimens, 3 dissected, $\mathrm{L}=4-8 \mathrm{~mm}$, NorthWest Pacific, Sea of Japan, Rudnaya bay, $44^{\circ} 29.775^{\prime} \mathrm{N} 136^{\circ} 09.075^{\prime} \mathrm{E}, 7-19 \mathrm{~m}$ in depth, 24.07.2020, coll. T. Antokhina, Yu. Deart.

ETYMOLOGY. This species is named in honor of Prof. Vladimir V. Malakhov, Head of the Invertebrate Zoology Department, Lomonosov Moscow State University. Prof. Vladimir V. Malakhov is a teacher of the authors of this paper, for many years he has shared knowledge and dedicated his time and efforts to inspire and foster research on invertebrate zoology in us and other young scientists. His contributions promoted studies of marine communities in the Russian Far East and greatly improved the knowledge on the NW Pacific marine fauna.

EXTERNAL MORPHOLOGY. Length up to $8 \mathrm{~mm}$. Body elongate, narrow. Cerata arranged in up to six distinct rows, up to four cerata per row. Dorsal cerata swollen, digestive gland occupies up to $50 \%$ of their volume. Lateral cerata tubular, digestive gland diverticula occupy almost all internal space. Oral tentacles and rhinophores simple, elongated, up to $0.8 \mathrm{~mm}$ in length. Rhinophores stout, smooth. Reproductive opening located laterally under second ceratal row at right. Anal opening acleio- proctic, behind first three ceratal rows at right.

COLOURATION. Background color translucent-white. Rhinophores with minute white pigmentation. Digestive gland diverticula from bright-orange to reddish-orange and clearly seen through translucent ceratal wall. Cnidosac areas marked with apical white pigmented caps (Fig. 10).

ANATOMY. Paired jaws triangle-shaped, thin and delicate, masticatory border of jaw with up to 10 distinct denticles (Figs 7E; 11A, B). Radular formula 32-39 × 1.1.1. Rachidian teeth with slightly compressed conical cusp and 3-4 large denticles on each side. In several rachidian teeth innermost denticles smaller than outer denticles. Lateral teeth triangle, plate-like, thin and delicate, with triangle attenuated processes at inner top. Ratio of length to width varies from $1: 1.5$ to $1: 2.5$ even in a single row (Figs $7 \mathrm{C}$; $11 \mathrm{C}-\mathrm{E})$.

Digestive gland with three main branches (right and left anterior and posterior), diverticula entering the cnidosacs, occupying each ceras top. Cnidosac oval, with distinct proliferation and cnidophage zones. Cnidosac musculature thin-walled with indistinct layers. Cnidophages large cells, containing large vacuoles with electron-transparent compound, and numerous nematocysts in granular part of cytoplasm. Distinct digestive vacuoles surrounding nematocysts. Haemocoel contains numerous amoebocytes. Epithelial cells with numerous vacuoles containing chitinous spindles, large mucous cells with electron-transparent compounds and specific cells with rounded electron-dense discs (Figs 8B; 12).

Reproductive system diaulic. Ampulla small bean-shaped sac. Prostatic vas deferens distinct, muscular, convoluted around midline, expands in muscular penial sac. Penial gland present, inserts into penial base. Penial stylet present, short. Receptaculum seminis large, muscular, bent in midline, slightly narrows into vagina (Fig. 7E).

GEOGRAPHIC RANGE. This species is only known from the type locality, the Sea of Japan, Rudnaya Bay, however it probably has wider distribution in the North-West Pacific. 

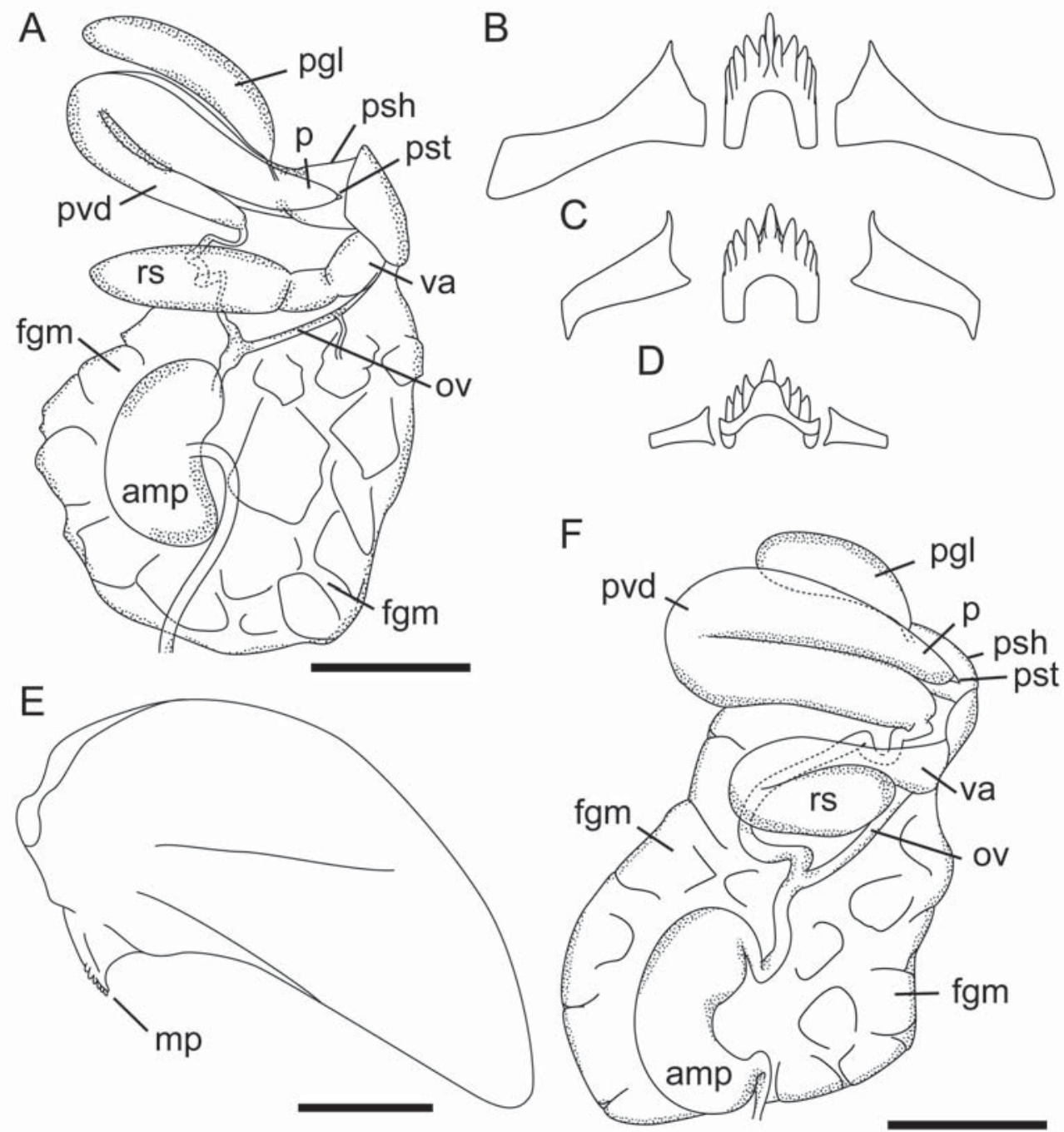

Fig. 7. Details of anatomy in Eubranchus odhneri-Eubranchus sanjuanensis species complex, schematic drawings. A - Eubranchus odhneri, reproductive system; B - Eubranchus odhneri, rachidian and lateral teeth, middle radular portion; C - Eubranchus malakhovi sp.n., rachidian and lateral teeth, middle radular portion; D - Eubranchus sanjuanensis, rachidian and lateral teeth, after Roller, 1972; E - Eubranchus malakhovi sp.n., right jaw plate; F - Eubranchus malakhovi sp.n., reproductive system.

Abbreviations: amp — ampulla; fgm — female gland mass; $\mathrm{mp}$ — masticatory process; ov — oviduct; $\mathrm{p}$ — penis; $\mathrm{pgl}$ penial gland; psh - penial sheath; pst — penial stylet; pvd - prostatic vas deferens; rs - receptaculum seminis; va - vagina. Scale bars: A $-1 \mathrm{~mm} ; \mathrm{E}-200 \mu \mathrm{m} ; \mathrm{F}-400 \mu \mathrm{m}$.

Рис. 7. Схематические изображения анатомических диагностических признаков различных видов комплекса Eubranchus odhneri - Eubranchus sanjuanensis. A - Eubranchus odhneri, половая система; В - Eubranchus odhneri, центральные и латеральные зубы, средняя часть радулы; C - Eubranchus malakhovi sp.n., центральные и латеральные зубы, средняя часть радулы; D-Eubranchus sanjuanensis, центральные и латеральные зубы, по Roller, 1972; E - Eubranchus malakhovi sp.n., левая челюстная пластика; F - Eubranchus malakhovi sp.n., половая система.

Обозначения: amp — ампулла; fgm — комплекс женских желез; $\mathrm{mp}$ - жевательный отросток; ov — овидукт; $\mathrm{p}$ пенис; pgl — пениальная железа; psh — карман пениса; pst — стилет пениса; pvd — простатический семяпровод; rs - семяприемник; va - вагина. Масштаб: А - 1 мм; Е - $200 \mu \mathrm{m} ; \mathrm{F}-400 \mu \mathrm{m}$. 


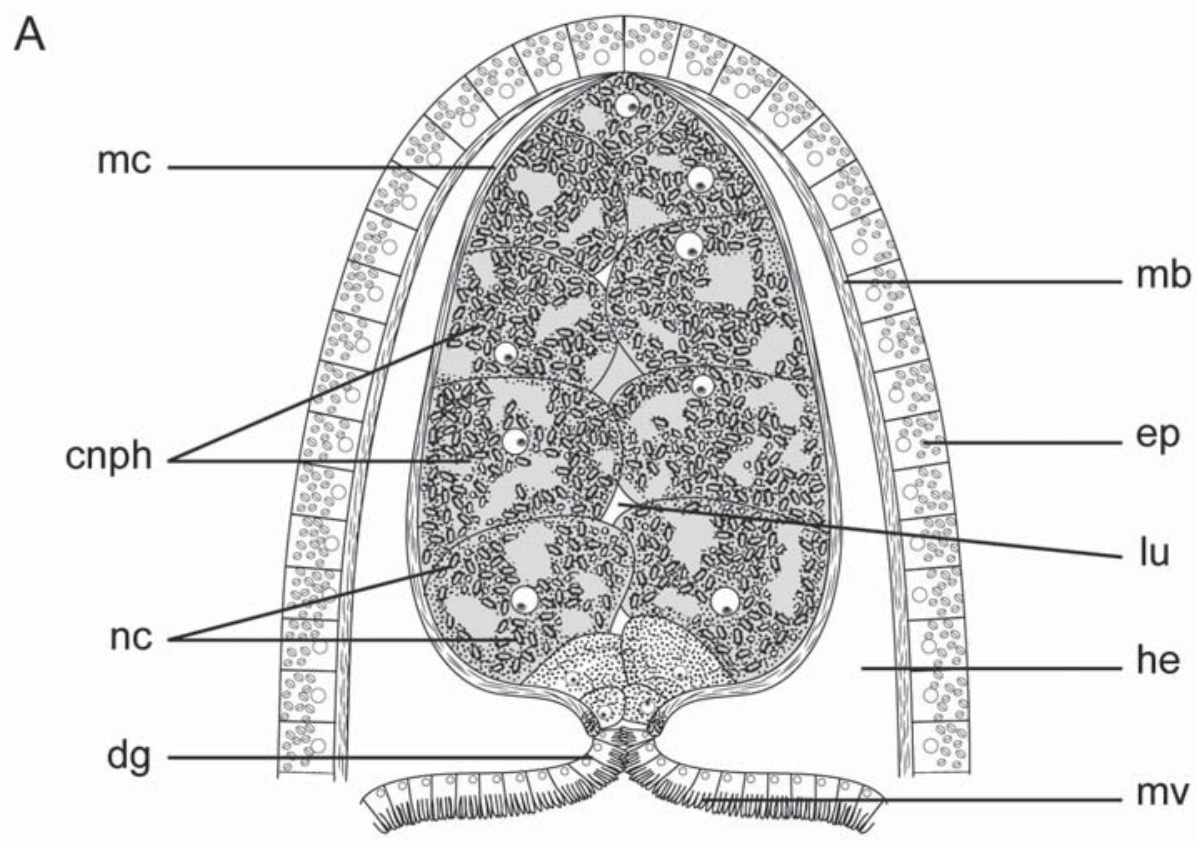

B

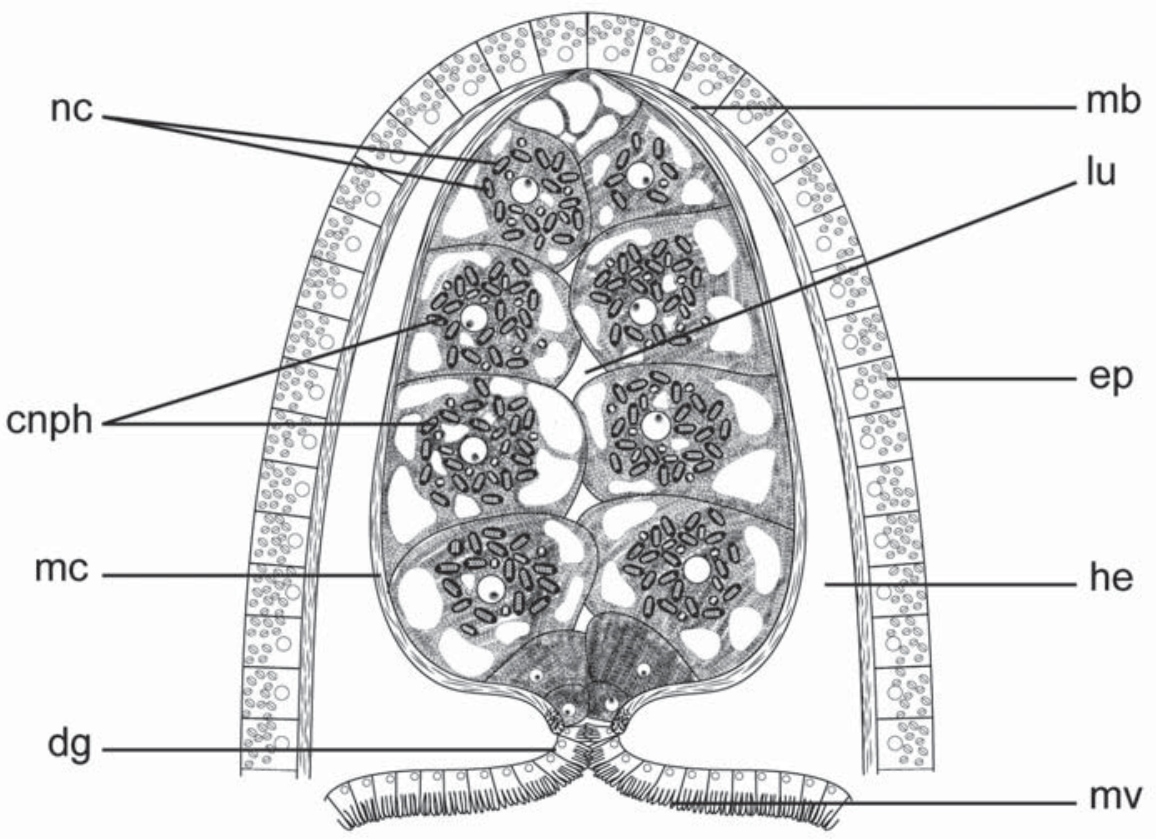

Fig. 8. Schematic representation of cnidosac area in Eubranchus malakhovi sp.n. and E. odhneri. A E. odhneri; B - E. malakhovi sp.n.

Abbreviations: cnph — cnidophages; dg — digestive gland; ep — epidermis; he — haemocoel; lu — lumen; $\mathrm{mb}$ — body wall musculature; $\mathrm{mc}$ - cnidosac musculature; $\mathrm{mv}$ - microvilli; $\mathrm{nc}$ - obtained nematocysts.

Рис. 8. Схематическое изображение зоны книдосаков Eubranchus malakhovi sp.n. и E. odhneri. A E. odhneri; B - E. malakhovi sp.n.

Обозначения: cnph — книдофаги; dg — пищеварительная железа; ер — эпидермис; he - гемоцель; lu — люмен; $\mathrm{mb}$ - мускулатура стенки тела; mc — мускулатура книдосака; mv — микровилли; nc — клептокниды. 

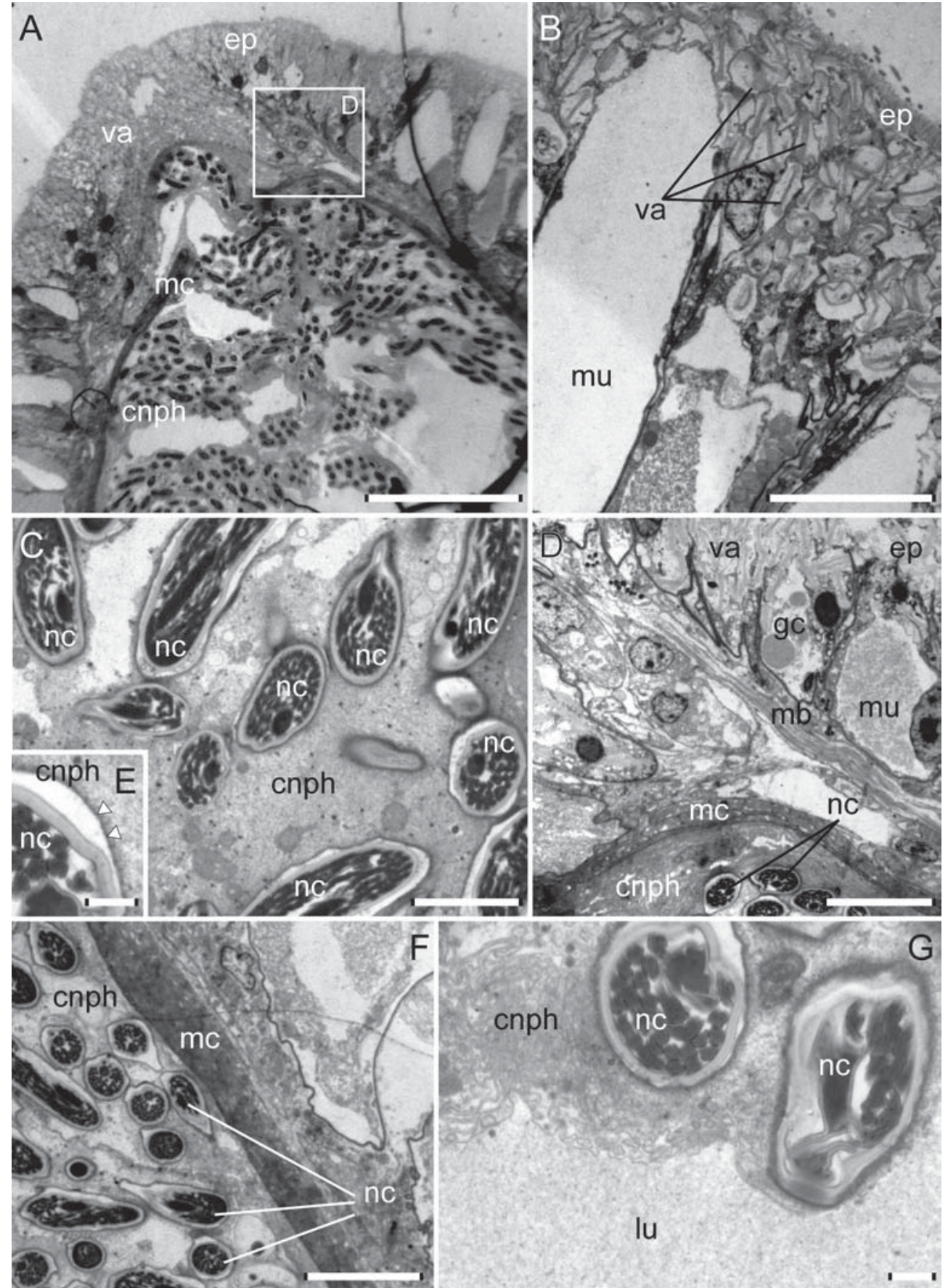

Fig. 9. Cnidosac ultrastructure in Eubranchus odhneri, TEM, longitudinal section. A - general view of distal ceras area; $\mathrm{B}$ - details of epidermis ultrastructure; $\mathrm{C}-\mathrm{F}$ - details of cnidophage zone ultrastructure, white triangles mark digestive vacuole in cnidophage cell; $\mathrm{G}$ - details of cnidophage and lumen. Abbreviations: cnph — cnidophage; gc — epidermal granular cells; ep — epidermal cells; lu — lumen; mb — body wall musculature; $\mathrm{mc}$ - cnidosac musculature; $\mathrm{mu}$ - mucous cell; $\mathrm{nc}$ - obtained nematocyst; va — vacuoles with chitinous spindles. Scale bars: A $-50 \mu \mathrm{m} ; \mathrm{B}, \mathrm{D}, \mathrm{F}-10 \mu \mathrm{m} ; \mathrm{C}-5 \mu \mathrm{m} ; \mathrm{E}, \mathrm{G}-1 \mu \mathrm{m}$. 

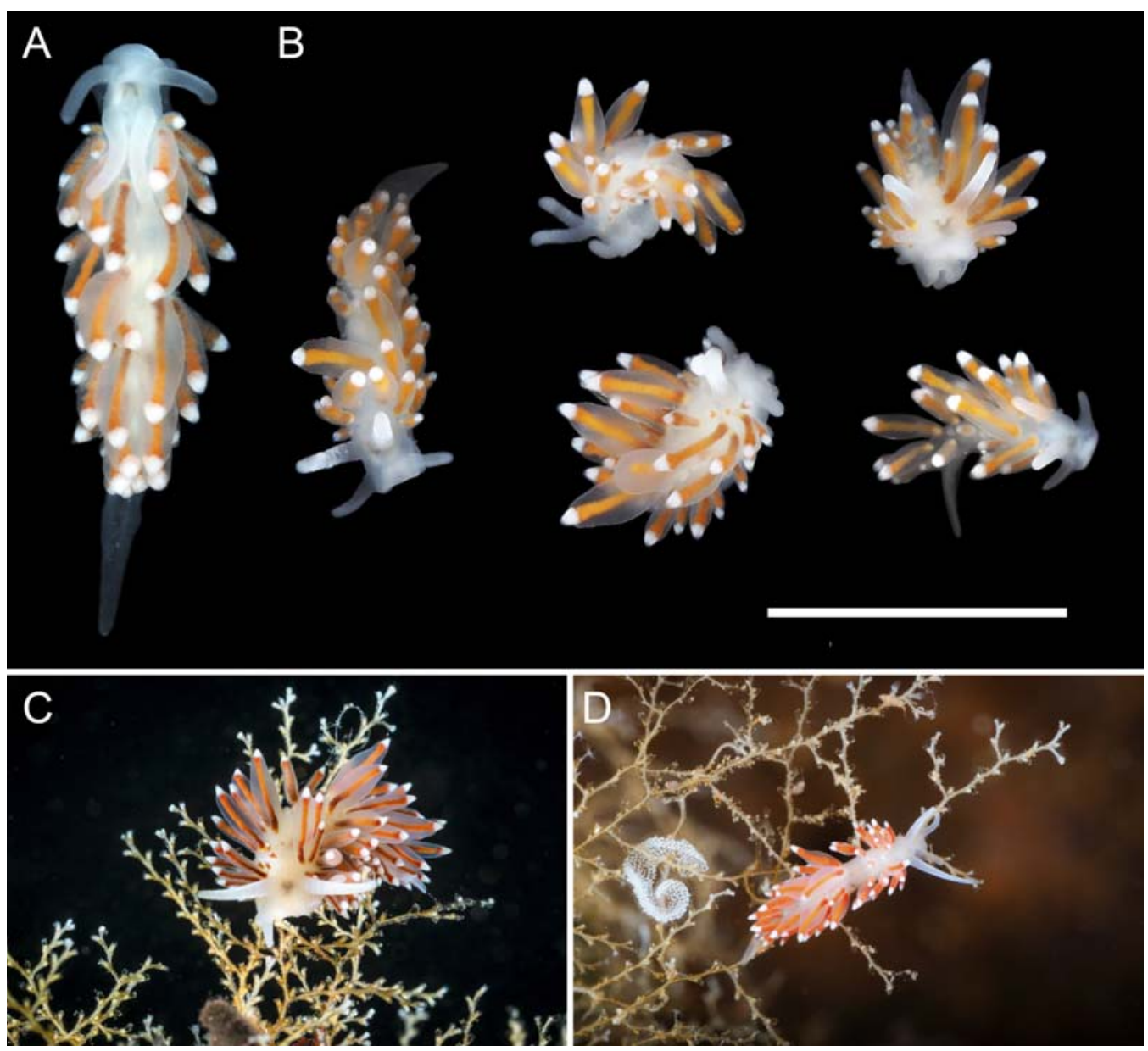

Fig. 10. Eubranchus malakhovi sp.n., living specimens. A - holotype MIMB42219, dorsal view; B MIMB42220-MIMB42224; C - living specimen in natural environment on unidentified sertulariid colony; D - living specimen in natural environment on unidentified colony with egg mass. Scale bar: $5 \mathrm{~mm}$. Рис. 10. Eubranchus malakhovi sp.n., прижизненные фотографии. А - голотип МІМВ42219, вид с дорсальной стороны; В - MIMB42220-MIMB42224; C - живой представитель в естественной среде обитания на неопределенной колонии сертуляриидных гидроидов; D - живой представитель и его кладка в естественной среде обитания на неопределенной колонии. Масштаб: 5 мм.

Рис. 9. Ультраструктура книдосаков Eubranchus odhneri, ТЭМ, продольный срез. А - общий вид дистальной части цераты; В - детали ультраструктуры эпидермиса; $\mathrm{C}-\mathrm{F}$ - детали ультраструктуры книдосака, белыми треугольниками отмечена пищеварительная вакуоль книдофага; $\mathrm{G}$ - область контакта книдофагов с просветом книдосака.

Обозначения: cnph — книдофаг; gc — эпидермальная клетка с гранулярными включениями; ер — эпидермальные клетки; lu — люмен; mb — мускулатура стенки тела; mc — мускулатура книдосака; mu — слизевая клетка; $\mathrm{nc}-$ клептокнида; va - вакуоли с гранулярным хитином. Масштаб: А $-50 \mu \mathrm{m} ; \mathrm{B}, \mathrm{D}, \mathrm{F}-10 \mu \mathrm{m}$; $\mathrm{C}-5 \mu \mathrm{m}$; $\mathrm{E}, \mathrm{G}-1 \mu \mathrm{m}$. 


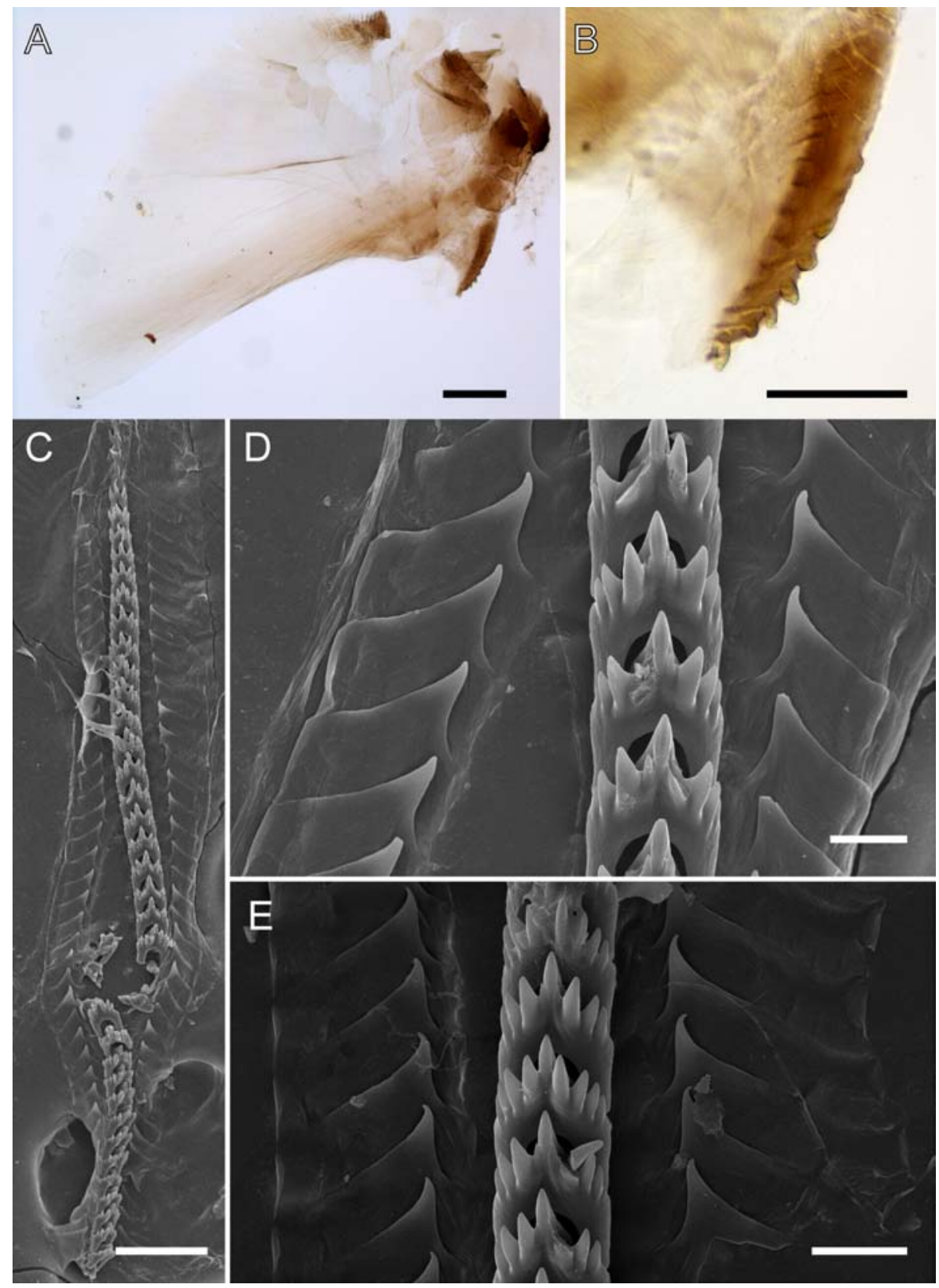

Fig. 11. Buccal armature in Eubranchus malakhovi sp.n. A - MIMB42226, left jaw plate, light microscopy; B - MIMB42226, details of masticatory border denticulation, light microscopy; C - MIMB42224, radula, SEM; D - MIMB42224, rachidian and lateral teeth, middle radular portion, SEM; E - MIMB42227, rachidian and lateral teeth, middle radular portion, SEM. Scale bars: A, C $-100 \mu \mathrm{m} ; \mathrm{B}-50 \mu \mathrm{m} ; \mathrm{D}, \mathrm{E}-$ $20 \mu \mathrm{m}$.

Рис. 11. Буккальное вооружение Eubranchus malakhovi sp.n. А - MIMB42226, левая челюстная пластинка, световая микроскопия; В - MIMB42226, детали зазубренности жевательного отростка челюсти, световая микроскопия; C - MIMB42224, радула, СЭМ; D - MIMB42224, центральные и латеральные зубы, средняя часть радулы, СЭМ; Е - МIMB42227, центральные и латеральные зубы, средняя часть радулы, СЭМ. Масштаб: А, C $-100 \mu \mathrm{m} ; \mathrm{B}-50 \mu \mathrm{m} ; \mathrm{D}, \mathrm{E}-20 \mu \mathrm{m}$. 


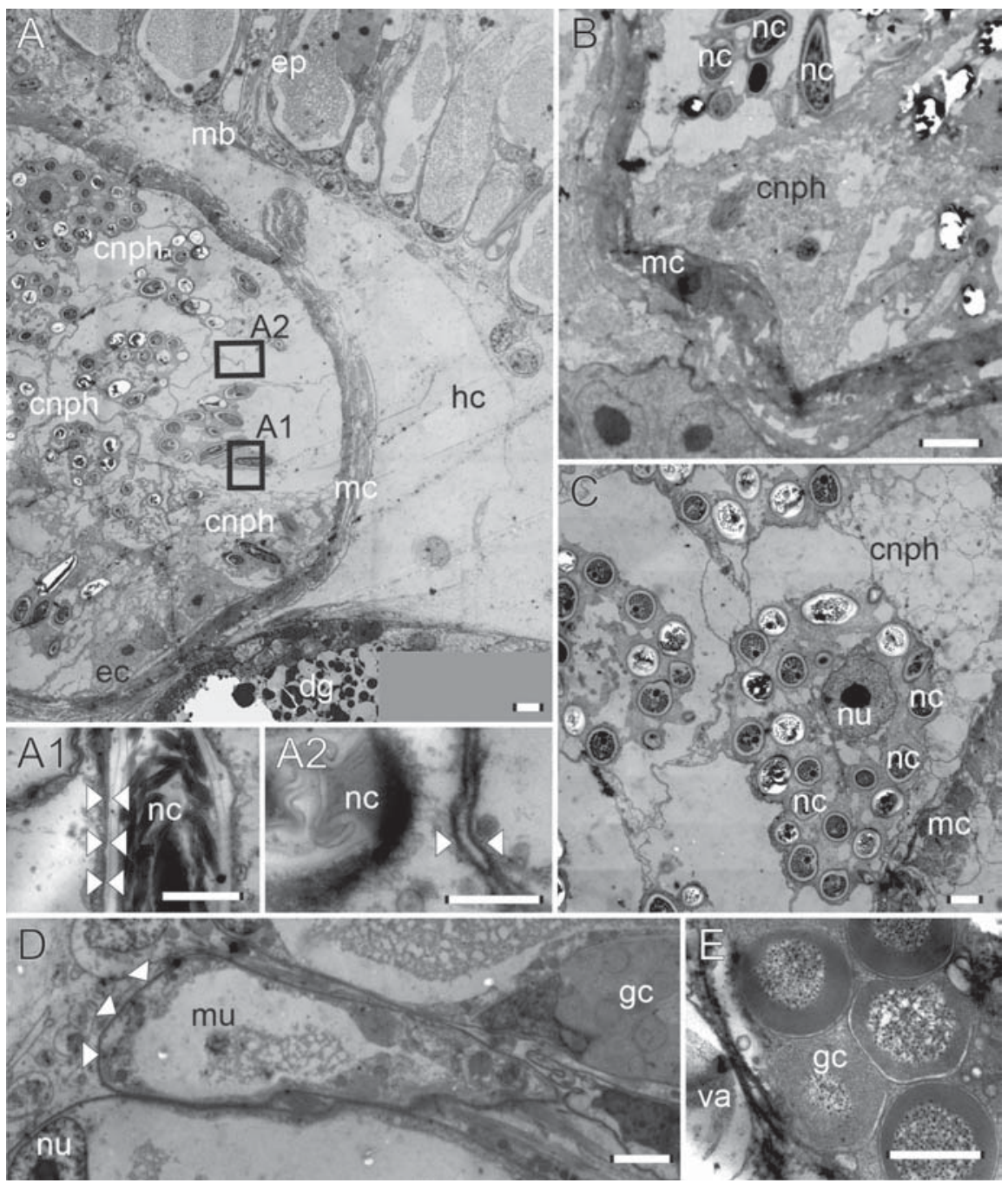

Fig. 12. Cnidosac ultrastructure in Eubranchus malakhovi sp.n., TEM, longitudinal section. A — general view of cnidosac proximal part with adjacent haemocoel and digestive gland diverticulum; A1, A2 — details of cnidophage zone showing nematocyst digestive vacuole (A1, white triangles) and cnidophages adherent junction (A2, white triangles). B, C - details of cnidophage zone; D - epidermis ultrastructure, white tangles indicate basal laminae; E - epidermal granular cell.

Abbreviations: cnph — cnidophage; dg — digestive gland; ec — "embryonic" cnidosac cells; ep — epidermal cells; $\mathrm{gc}$ - epidermal granular cell; hc - haemocoel; $\mathrm{mb}$ - body wall musculature; $\mathrm{mc}$ - cnidosac musculature; $\mathrm{mu}-$ mucous cell; nc — obtained nematocysts; nu — nucleus; va — vacuoles with chitinous spindles. Scale bars: A, B $10 \mu \mathrm{m} ; \mathrm{A} 1, \mathrm{~A} 2-2 \mu \mathrm{m} ; \mathrm{C}-\mathrm{E}-5 \mu \mathrm{m}$.

Рис. 12. Ультраструктура книдосаков Eubranchus malakhovi sp.n., ТЭМ, продольный срез. А общий вид проксимальной части книдосака с прилегающим гемоцелем и дивертикулом пищеварительной железы; A1, A2 - детали ультраструктуры книдофагов, пищеварительная вакуоль нематоцисты (А1, белые треугольники) и клеточные контакты книдофагов (А2, белые треугольники). В, С зона книдофагов; D - ультраструктура эпидермиса, белыми треугольниками обозначена базальная пластинка; E - эпидермальная клетка с гранулированным содержимым.

Обозначения: cnph — книдофаг; dg — пищеварительная железа; еc — «эмбриональные» клетки книдосака; ep эпидермальные клетки; mb - мускулатура стенки тела; mc — мускулатура книдосака; mu — слизевая клетка; $\mathrm{gc}$ - эпидермальная клетка с гранулярными включениями; hc - гемоцель; nc - клептокниды; nu - ядро; va вакуоли с хитиновыми гранулами. Масштаб: А, В $-10 \mu \mathrm{m} ; \mathrm{A} 1, \mathrm{~A} 2-2 \mu \mathrm{m}$; $\mathrm{C}-\mathrm{E}-5 \mu \mathrm{m}$. 
BIOLOGY. This species was found on different hydrozoans, including Obelia spp. and several Sertulariidae species. Egg mass is a single-coiled spiral.

REMARKS. Eubranchus malakhovi sp.n. differs from its closest relative, E. odhneri from Arctic waters by having a shorter body and some other minor differences in colouration, radular morphology, reproductive system and cnidosac ultrastructure. Specifically, adult E. odhneri reach up to $20 \mathrm{~mm}$ in length, with more ceratal rows and number of cerata per row than $E$. odhneri (Fig. 5). In E. odhneri color of digestive gland diverticula varies from brownish red to pale reddish, sometimes reddish orange, however E. malakhovi sp.n. usually has bright orange diverticula. In E. odhneri the white pigmentation of the rhinophores is indistinct, e.g. white dots are sparse if present, while in $E$. malakhovi sp.n. this pigmentation is obvious (Figs 5; 10). Internally, E. odhneri possesses longer lateral teeth than E. malakhovi sp.n., e.g. ratio length to width is up to $1: 4$ in E. odhneri, and only 1:2.5 in E. malakhovi sp.n. (Fig. 7B, D). Also, E. odhneri possesses more rows of teeth (up to 58 in MIMB 42217) (Figs 6C; 11C). The jaw morphology is similar in the two species (Figs 6A, B; 7E; 11A, B). Reproductive system configuration quite similar in the two species, however, in E. malakhovi sp.n. the receptaculum seminis is bent in the midline, while it is straight in E. odhneri (Fig. 7A, F). Finally, in cnidosacs of E. malakhovi sp.n. the cnidophages contain numerous closely packed large vacuoles with electron-transparent compound, when electron-transparent areas within E. odhneri cnidophages are not enclosed into a vacuole. Other ultrastructural features of cnidosacs in these two species are in general similar, however in E. odhneri the cnidophages contain another nematocysts type in larger number.

Another Pacific species from Washington and British Columbia, E. sanjuanensis also show several differences with E. malakhovi sp.n. Although the size of these two species is similar as well as the general colouration, E. sanjuanensis differs in external morphology from E. malakhovi sp.n. by having translucent rhinophores.
Eubranchus sanjuanensis has much shorter triangle lateral teeth (length to width ratio is almost 1:1) and less denticles on the rachidian tooth (3) (Fig. 7D). It also possesses more teeth rows (up to 50). Unfortunately, the reproductive system of E. sanjuanensis was not studied in detail.

\section{Discussion}

Our results clearly show Eubranchus malakhovi sp.n., E. odhneri and E. sanjuanensis represent a complex of three close, but distinct species. Although our phylogenetic analysis revealed quite low support of most branches due to low taxon sampling and heterogeneity in sequencing efforts, the Eubranchus odhneriE. sanjuanensis species complex in general as well as each target species are monophyletic and highly supported (Fig. 2). Both COI and $18 \mathrm{~S}$ datasets show that E. malakhovi sp.n. differs from both E. odhneri and E. sanjuanensis (Fig. 3), and E. malakhovi sp.n. is recovered as a well-supported monophyletic group in the concatenated phylogenetic analysis (Fig. 2). The GMYC analysis clearly separates all three species, however other delimitation approaches tend to either oversplit (bPTP) or overlump (ASAP) sample groups in comparison to our initial species hypothesis. The overlumped species delimitation result is most likely an artefact of delimitation approaches. ASAP (Fig. S1) is based on detecting a single barcode gap for the whole group (Puillandre et al., 2021). Thus it is unsuited for cases when different species have been formed at different times. The bPTP method should mitigate such problems, as it is based on tree topology and node support, not only branch lengths (Zhang et al., 2013). In our case bPTP fails to delimit species correctly as our COI-based ML tree is not well-resolved enough due to low substitution rates at species level (Data S1).

The molecular clock analysis estimates the age of the most recent common ancestor of $E$. malakhovi sp.n. and E. odhneri is $\sim 1.5$ Mya (Fig. 4). The relatively short period of time that elapsed since their divergence, and the small 
genetic distances between them (2.48-3.38\%), are in no way inconsistent with $E$. malakhovi sp.n. and E. odhneri separation as distinct species. Low values of $p$-distances are quite common for trans-Arctic sister species, which speciation is likely affected by the Bering Strait paleogeography: for Acanthodoris pilosa (Abildgaard [in Müller], 1789) and A. atrogriseata O'Donoghue, 1927 (Doridina: Onchidorididae) the COI $p$-distance is $4.47 \%$ (Hallas et al., 2016), for Dendronotus lacteus and D. rufus it is 3.37\% (Ekimova et al., 2019b) and for Microchlamylla gracilis (Alder et Hancock, 1844) and M. amabilis (Hirano et Kuzirian, 1991) it is 3.8\% (Korshunova et al., 2017; Ekimova et al., in press). There is no data on overlap of geographic ranges and differences in nDNA (Fig. 3B) show no evidence of possible areas of secondary contact. Analysis of morphological traits also supports this viewpoint, we found consistent differences in both external (colouration of rhinophores) and internal (radula, the reproductive system) morphology and also in the cnidosac ultrastructure (Figs 5-12). Differences found in the morphology of the digestive system, i.e. radular characters and cnidosac ultrastructure may suggest different diets. However, we did not find any evidence of ecological differences as the two species were found on similar hydrozoan colonies (family Sertulariidae), as well as E. sanjuanensis was also found on Sertularella sp. (Roller, 1972).

Speciation within E. sanjuanensis - E. odhneri species complex may be explained by two concepts with different hypotheses: allopatric speciation or ecological radiation. Amphiboreal molluscs can have very subtle differences in morphology (Ekimova et al., 2019b), as both abiotic conditions and marine communities are quite similar (Vermeij, 1991). Distributional ranges and estimated divergence times suggest that three studied species could be allopatric species formed following Pliocene and Pleistocene climate changes and subsequent opening and closing of the Bering Strait (Briggs, 1995; Avise, 2000; Marinkovich, 2000; Gladenkov et al., 2002; Gladenkov, 2006; Lyle et al., 2008; Matthiessen et al., 2009; Laakkonen et al.,
2021). Frequent events isolating populations in similar habitats led to a multitude of recently diverged sister species, occupying identical niches in different locations (Carlton et al., 1991; Vermeij, 1991; Nakano, Ozawa, 2004; Ekimova et al., 2019b). Depending on chance and population sizes either no significant morphologic divergence from ancestral lineages, or high plasticity of traits may be expected. At the same time, some morphological differences indicate that other drivers might cause speciation at least in case of E. malakhovi sp.n. and $E$. odhneri. The latter species has larger body size comparing to both E. malakhovi sp.n. and $E$. sanjuanensis, and all three species display different morphology of radula (Figs 6; 7B-D; 11). It has been suggested that the evolution of nudibranch molluscs is driven by specialization on specific diet resulting in different feeding modes (Cimino, Ghiselin, 1999; Wägele, 2004; Burghardt et al., 2008; Göbeller, KlussmanKolb, 2011; Goodheart et al., 2017; Mikhlina et $a l ., 2020)$. It also has been suggested that evolutionary prey shift promotes changes in the feeding apparatus and, in particular, in the radular morphology (Young, 1969; Valdés, 2004; Belmonte et al., 2015; Cella et al., 2016; Korshunova et al., 2017; Ekimova et al., 2019a, b). Consequently, different radular morphologies in close species may suggest diet-driven ecological speciation (Ekimova et al., 2019b). We do not have enough evidence to distinguish whether these species were formed allopatrically and later acquired morphological differences, or diverged sympatrically on different food sources and later expanded to different areas. In either case both morphologically and genetically E. malakhovi sp.n. is distinct from its both sister species.

\section{Compliance with ethical standards}

CONFLICTS OF INTEREST: The authors declare that they have no conflicts of interest.

Supplementary data. The following materials are available online.

Table S1. Specimens used for molecular analyses. Voucher numbers, collection locali- 
ties and GenBank accession numbers are given. Sequences obtained for this study are highlighted in bold.

Fig. S1. Species delimitation results from ASAP analysis showing species groups with different ASAP scores.

Data S1. Unedited Maximum likelihood phylogenetic trees based on a single marker (COI, 16S, H3).

Acknowledgements. We want to express our special gratitude to Andrey Shpatak, who was the first discoverer of the new species and shared with us its beautiful underwater pictures; in addition, he kindly hosted us during the field trip to the Sea of Japan and assisted during numerous dives. We are also deeply grateful to friends who helped with collection of material used in this study: Alexander Semenov, Yury Deart. Maria Stanovova is thanked for assistance in Sanger sequencing. Molecular study was conducted using equipment of the Core Centrum of Institute of Developmental Biology RAS and molecular lab at the Invertebrate Zoology Department, Lomonosov Moscow State University. We also want to thank the staff of the scanning electron microscopic laboratory of the Moscow State University for providing SEM facilities. Ángel Valdés and one anonymous reviewer are thanked for providing very constructive and useful comments, that helped a lot for improvements of this paper. This study was conducted in frame of scientific project of the State Order of the Russian Federation Government to Lomonosov Moscow State University No. 121032300121-0 with financial support of Russian Science Foundation grant no. 19-7400144 to DS (morphological examination, sampling, molecular studies and computation analyses). Ecological observations and morphological studies of cnidosacs were conducted with the support of Russian Foundation for Basic Research grant no. 20-34-70044 to IE, AM, TA and DS. Depository of specimens used in this study was supported by Moscow State University Grant for Leading Scientific Schools "Depository of the Living Systems" in frame of the MSU Development Program. There was no additional external funding received for this study.

\section{References}

Avise J.C. 2000. Phylogeography: The History and Formation of Species. Cambridge, Massachusetts: Harvard University Press. 464 p.

Avise J.C. 2004. Molecular markers, natural history, and evolution. 2nd ed. Sunderland, MA: Sinauer Associates. 684 p.

Belmonte T., Alvim J., Padula V., Muricy G. 2015. Spongivory by nudibranchs on the coast of Rio de Janeiro state, southeastern Brazil // Spixiana. Vol.38. P.187195.

Bergh R. 1886. Die Nudibranchien gesammelt während der Fahrten des „Willem Barents” in das Nördliche Eismeer // Bijdragen tot de Dierkunde. Vol.13. P.137.

Bouckaert R., Vaughan T.G., Barido-Sottani J., Duchêne S., Fourment M., Gavryushkina A., Matschiner M. 2019. BEAST 2.5: An advanced software platform for Bayesian evolutionary analysis // PLoS Comput. Biol. Vol.15. No.4. e1006650.

Bowen B.W., Gaither M.R., DiBattista J.D., Iacchei M., Andrews K.R., Grant W.S., Toonen R.J., Briggs J.C. 2016. Comparative phylogeography of the ocean planet // P. Natl. Acad. Sci. Vol.113. No.29. P.7962-7969.

Briggs J.C. 1995. Global biogeography // Developments in Palaeontology and Stratigraphy. Elsevier. Vol.14.

Burghardt I., Schrödl M., Wägele H. 2008. Three new solar-powered species of the genus Phyllodesmium Ehrenberg, 1831 (Mollusca: Nudibranchia: Aeolidioidea) from the tropical Indo-Pacific, with analysis of their photosynthetic activity and notes on biology // J. Mollus. Stud. Vol.74. No.3. P.277-292.

Burn R. 1964. Descriptions of Australian Eolidacea (Mollusca: Opisthobranchia) The Genera Nossis, Eubranchus, Trinchêsia and Toorna // J. Malac. Soc. Aust. Vol.1. P.10-22.

Carlton J.T., Vermeij G.J., Lindberg D.R., Carlton D.A., Dubley E.C. 1991. The first historical extinction of a marine invertebrate in an ocean basin: the demise of the eelgrass limpet Lottia alveus // Biol. Bull. Vol.180. No.1. P.72-80.

Cella K., Carmona L., Ekimova I., Chichvarkhin A., Schepetov D., Gosliner T.M. 2016. A radical solution: the phylogeny of the nudibranch family Fionidae // PloS one. Vol.11. e0167800.

Chaban E.M., Ekimova I.A., Schepetov D.M., Chernyshev A.V. 2019. Meloscaphander grandis (Heterobranchia: Cephalaspidea), a deep-water species from the North Pacific: Redescription and taxonomic remarks // Zootaxa. Vol.4646. No.2. P.385-400.

Cimino G., Ghiselin M.T. 1999. Chemical defense and evolutionary trends in biosynthetic capacity among dorid nudibranchs (Mollusca: Gastropoda: Opisthobranchia) // Chemoecology. Vol.9. No.4. P.187-207. 
Clarke A., Crame J. A. 2010. Evolutionary dynamics at high latitudes: speciation and extinction in polar marine faunas // Philos. T. Roy. Soc. B. Vol.365. No.1558. P.3655-3666.

Clement M., Snell Q., Walke P., Posada D., Crandall K. 2002. TCS: estimating gene genealogies // Processing 16th International Parallel and Distributed Processing Symposium. Vol.2. P.184.

Colgan D.J., McLauchlan A., Wilson G.D.F., Livingston S.P., Edgecombe G.D., Macaranas J., Gray M.R. 1998. Histone H3 and U2 snRNA DNA sequences and arthropod molecular evolution // Aust. J. Zool. Vol.46. No.5. P.419-437.

Darriba D., Posada D., Kozlov A.M., Stamatakis A., Morel B., Flouri T. 2020. ModelTest-NG: a new and scalable tool for the selection of DNA and protein evolutionary models // Mol. Biol. Evol. Vol.37. No.1. P.291-294.

Derjugin K.M., Gurjanova E.F. 1926. [New species of the molluscs from the Russian Northern Seas] // Trudy Leningradsk. obshchestva estestvoispytatelei. Vol.56. P.17-26 [in Russian].

Edgar R.C. 2004. MUSCLE: multiple sequence alignment with high accuracy and high throughput // Nucleic Acids Res. Vol.32. No.5. P.1792-1797.

Edmunds M., Kress A. 1969. On the European species of Eubranchus [Mollusca Opisthobranchia] // J. Mar. Biol. Assoc. UK. Vol.49. P.879-912.

Ekimova I., Deart Y., Schepetov D. 2019a. Living with a giant parchment tube worm: a description of a new nudibranch species (Gastropoda: Heterobranchia) associated with the annelid Chaetopterus // Mar. Biodiv. Vol.49. P.289-300.

Ekimova I., Valdés Á., Chichvarkhin A., Antokhina T., Lindsay T., Schepetov D. 2019b. Diet-driven ecological radiation and allopatric speciation result in high species diversity in a temperate-cold water marine genus Dendronotus (Gastropoda: Nudibranchia) // Mol. Phylogenet. Evol. Vol.141. Art.106609.

Ekimova I., Valdés Á., Malaquias M.A.E., Rauch C., Chichvarkhin A., Mikhlina A., Antokhina T., Chichvarkhina O., Schepetov D. 2021. High-level taxonomic splitting in allopatric taxa causes confusion downstream: a revision of the nudibranch family Coryphellidae // Zool. J. Linn. Soc. In press.

Folmer O., Black M., Hoeh W., Lutz R., Vrijenhoek R. 1994. DNA primers for amplification of mitochondrial cytochrome c oxidase subunit I from diverse metazoan invertebrates // Mol. Mar. Biol. Biotechnol. Vol.3. P.294-299.

Fujisawa T., Barraclough T.G. 2013. Delimiting species using single-locus data and the Generalized Mixed Yule Coalescent approach: a revised method and evaluation on simulated data sets // Syst. Biol. Vol.62. No.5. P.707-724.

Giribet G., Carranza S., Baguñà J., Riutort M., Ribera C. 1996. First molecular evidence for the existence of a Tardigrada + Arthropoda clade // Mol. Biol. Evol. Vol.13. No.1. P.76-84.

Gladenkov A.Y. 2006. Neogene diatoms from the Sandy Ridge section, Alaska Peninsula: significance for strati- graphic and paleogeographic reconstructions // Stratigr. Geol. Correl. Vol.14. No.1. P.73-90.

Gladenkov A.Y., Oleinik A.E., Marincovich Jr.L., Barinov K.B. 2002. A refined age for the earliest opening of Bering Strait // Palaeogeogr. Palaeocl. Vol.183. No.3-4. P.321-328.

Göbbeler K., Klussmann-Kolb A. 2011. Molecular phylogeny of the Euthyneura (Mollusca, Gastropoda) with special focus on Opisthobranchia as a framework for reconstruction of evolution of diet // Thalassas. Vol.27. No.2. P.121-154.

Goodheart J.A., Bazinet A.L., Valdés Á., Collins A.G., Cummings M.P. 2017. Prey preference follows phylogeny: evolutionary dietary patterns within the marine gastropod group Cladobranchia (Gastropoda: Heterobranchia: Nudibranchia) // BMC Evol. Biol. Vol.17. No.221.

Hallas J.M., Simison W.B., Gosliner T.M. 2016. Dating and biogeographical patterns in the sea slug genus Acanthodoris Gray, 1850 (Mollusca, Gastropoda, Nudibranchia)// Mol. Phylogenet. Evol. Vol.97. P.1931.

Herbert P.D.N., Cywinska A., Ball S.L., DeWaard J.R. 2003. Biological identifications through DNA barcodes // Proc. R. Soc. Ser. B-Bio. Vol.270. P.313321. https://doi.org/10.1098/rspb.2002.2218.

Ivanova N.V., Dewaard J.R., Hebert P.D. 2006. An inexpensive, automation?friendly protocol for recovering high-quality DNA // Mol. Ecol. Notes. Vol.6. No.4. P.998-1002.

Knowlton N. 2000. Molecular genetic analyses of species boundaries in the sea // Hydrobiologia. Vol.420. No.1. P.73-90.

Korshunova T., Martynov A., Bakken T., Evertsen J., Fletcher K., Mudianta I.W., Saito H., Lundin K., Schrödl M., Picton B. 2017. Polyphyly of the traditional family Flabellinidae affects a major group of Nudibranchia: aeolidacean taxonomic reassessment with descriptions of several new families, genera, and species (Mollusca, Gastropoda) // ZooKeys. Vol.717. P.1-139.

Korshunova T., Malmberg K., Prkić J., Petani A., Fletcher K., Lundin K., Martynov A. 2020. Fine-scale species delimitation: speciation in process and periodic patterns in nudibranch diversity // ZooKeys. Vol.917. P.15-50.

Laakkonen H.M., Hardman M., Strelkov P., Väinölä R. 2021. Cycles of trans-Arctic dispersal and vicariance, and diversification of the amphiboreal marine fauna // J. Evol. Biol. Vol.34. No.1. P.73-96.

Layton K.K., Corstorphine E.A., Hebert P.D. 2016. Exploring Canadian echinoderm diversity through DNA barcodes // PloS ONE. Vol.11. No.11. e0166118.

Leigh J.W., Bryant D. 2015. PopART: Full-feature software for haplotype network construction // Methods. Ecol. Evol. Vol.6. No.9. P.1110-1116.

Loeza-Quintana T., Adamowicz S.J. 2018. Iterative calibration: a novel approach for calibrating the molecular clock using complex geological events // J. Mol. Evol. Vol.86. No.2. P.118-137. 
Lyle M., Barron J., Bralower T.J., Huber M., Lyle A.O., Ravelo A.C., Wilson P.A. 2008. Pacific Ocean and Cenozoic evolution of climate // Rev. of Geophys. Vol.46. P.1-47.

Marincovich Jr.L. 2000. Central American paleogeography controlled Pliocene Arctic Ocean molluscan migrations // Geology. Vol.28. No.6. P.551-554.

Martynov A.V., Korshunova T.A., Savinkin O.V. 2006. Shallow-water opisthobranch molluscs of the Murman coast of the Barents Sea, with new distributional data and remarks on biology // Ruthenica. Vol.16. No.1-2. P.59-72.

Matthiessen J., Knies J., Vogt C., Stein R. 2009. Pliocene palaeoceanography of the Arctic Ocean and subarctic seas // Philos. T. Roy. Soc. A. Vol.367. No.1886. P.21-48.

Mikhlina A., Ekimova I., Vortsepneva E. 2020. Functional morphology and post-larval development of the buccal complex in Eubranchus rupium (Nudibranchia: Aeolidida: Fionidae) // Zoology. Vol.143. Art.125850.

Millen S.V. 1983. Range extensions of opisthobranchs in the northeastern Pacific // Veliger. Vol.25. No.4. P.383-386.

Millen S.V. 1989. Opisthobranch Range Extensions in Alaska with the First Records of Cuthona viridis (Forbes, 1840) from the Pacific // Veliger. Vol.32. No.1. P.64-68.

Millonig G. 1964. Study on the factors which influence preservation of fine structure // Symposium on electron microscopy. Rome, Italy: Consiglio Nazionale delle Ricerche. P.347.

Minh B.Q., Nguyen M.A.T., von Haeseler A. 2013. Ultrafast approximation for phylogenetic bootstrap // Mol. Biol. Evol. Vol.30. No.5. P.1188-1195.

MolluscaBase eds. 2021. MolluscaBase. Eubranchus Forbes, 1838. Accessed at: http://www.molluscabase. org/aphia.php? $\mathrm{p}=$ taxdetails\&id $=137954$ on 2021-0430

Nakano T., Ozawa T. 2004. Phylogeny and historical biogeography of limpets of the order Patellogastropoda based on mitochondrial DNA sequences // J. Mollus. Stud. Vol.70. No.1. P.31-41.

Palumbi S., Martin A., Romano S., McMillan W.O., Stice L., Grabowski G. 1991. The simple fool's guide to PCR, Ver. 2.0 Honolulu, University of Hawaii. 40 p.

Pons J., Barraclough T.G., Gomez-Zurita J., Cardoso A., Duran D.P., Hazell S., Kamoun S., Sumlin W.D.,
Vogler A.P. 2006. Sequence-based species delimitation for the DNA taxonomy of undescribed insects // Syst. Biol. Vol.55. No.4. P.595-609.

Puillandre N., Brouillet S., Achaz G. 2021. ASAP: assemble species by automatic partitioning // Mol. Ecol. Resour. Vol.21. P.609-620. https://doi.org/10.1111/ 1755-0998.13281

Puslednik L., Serb J.M. 2008. Molecular phylogenetics of the Pectinidae (Mollusca: Bivalvia) and effect of increased taxon sampling and outgroup selection on tree topology // Mol. Phylogenet. Evol. Vol.48. No.3. P.1178-1188.

Roginskaya I.S. 1987. [Order Nudibranchia Blainville, 1814] // Molluski Belogo Morya. Opredeliteli po faune SSSR. Leningrad. Vol.151. P.155-201 [in Russian].

Roller R.A. 1972. Three new species of eolid nudibranchs from the west coast of North America // Veliger. Vol.14. No.4. P.416-423.

Ronquist F., Huelsenbeck J.P. 2003. MrBayes 3: Bayesian phylogenetic inference under mixed models // Bioinformatics. Vol.19. No.12. P.1572-1574.

Stamatakis A. 2014. RAxML version 8: a tool for phylogenetic analysis and post-analysis of large phylogenies // Bioinformatics. Vol.30. No.9. P.1312-1313.

Valdés Á. 2004. Phylogeography and phyloecology of dorid nudibranchs (Mollusca, Gastropoda) // Biol. J. Linn. Soc.-Lond.. Vol.83. P.551-559.

Vermeij G.J. 1991. Anatomy of an invasion: the transArctic interchange // Paleobiology. Vol.17. No.3. P.281-307.

Wägele H. 2004. Potential key characters in Opisthobranchia (Gastropoda, Mollusca) enhancing adaptive radiation // Org. Divers. Evol. Vol.4. No.3. P.175-188.

Whiting M.F., Carpenter J.M., Wheeler Q.D., Wheeler W.C. 1997. The Strepsiptera problem: phylogeny of the holometabolous insect orders inferred from $18 \mathrm{~S}$ and 28S ribosomal DNA sequences and morphology // Syst. Biol. Vol.46. P.1-68.

Young D. 1969. The functional morphology of the feeding apparatus of some Indo-West-Pacific dorid nudibranchs // Malacologia. Vol.9. P.421-446.

Zhang J., Kapli P., Pavlidis P., Stamatakis A. 2013. A general species delimitation method with applications to phylogenetic placements // Bioinformatics. Vol.29. No.22. P.2869-2876.

Responsible editor A.V. Chernyshev 